
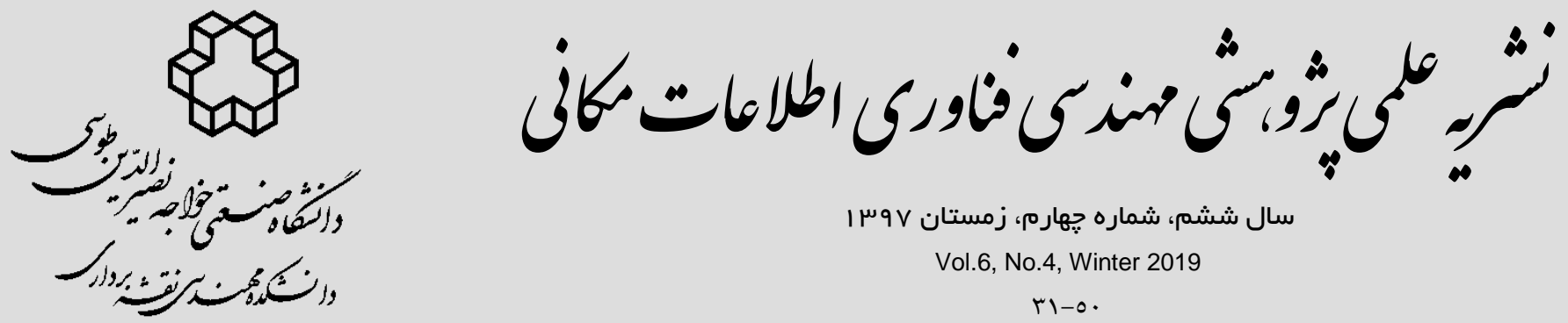

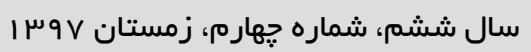

Vol.6, No.4, Winter 2019

M-O.

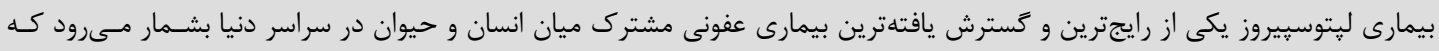

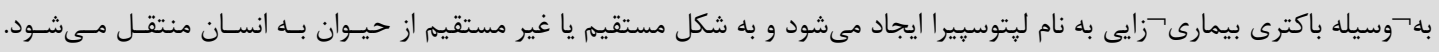

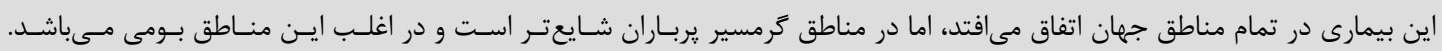

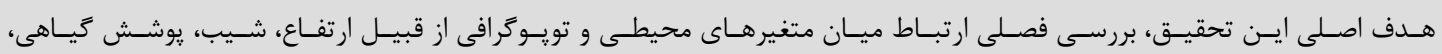

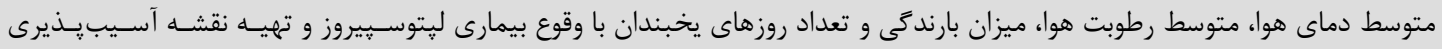

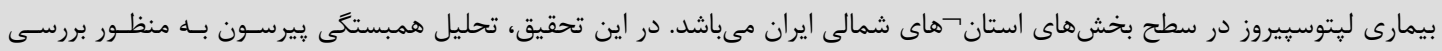

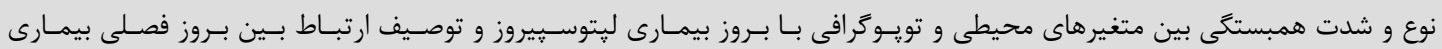

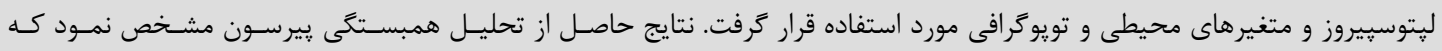

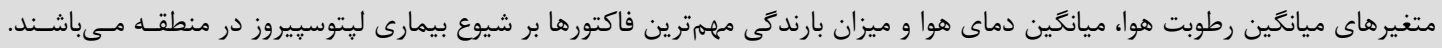

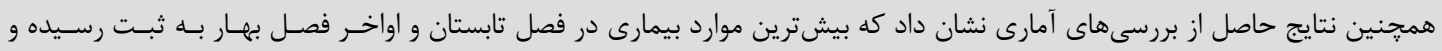

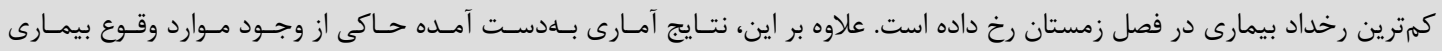

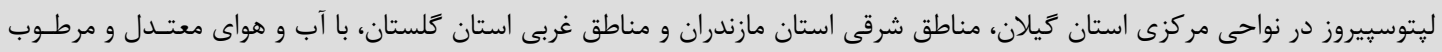

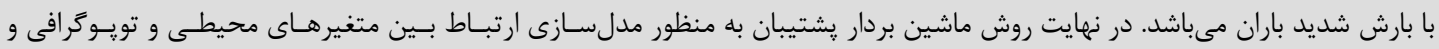

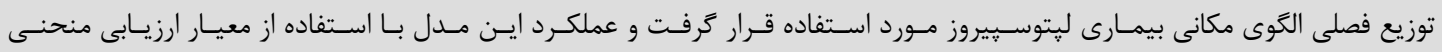

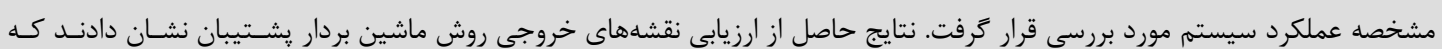

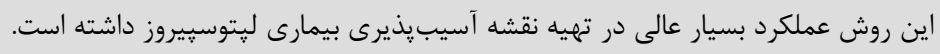

وازههاى كليدى: تحليل يِيرسون، سامانه اطلاعات مكانى، ماشين بردار يشتيبان، منحنى مشخصه عملكرد سيستم، بيمارى لِتوسيروز

* نويسنده مكاتبه كننده: : تهران- خيابان وليعصر - تقاطع ميرداماد غربى - دانشكده زئودزى و رئوماتيك- دانشكاه صنعتى خواجه نصيرالدين طوسى. تلفن: 
يك بيمارى سنتى روستايى كـهـ باعثث افززايش شـيوع

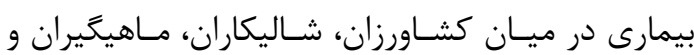

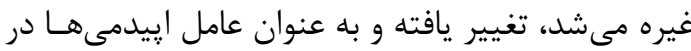

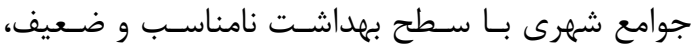

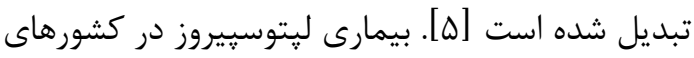

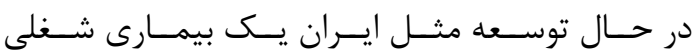
محسوب مى شود و بيشتر در ميان كشاورزان، دامداران،

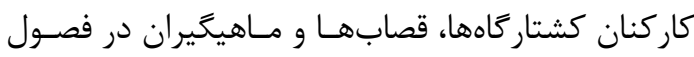

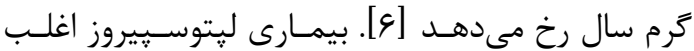

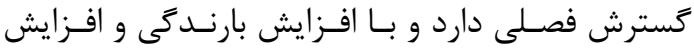
درجه حرارت بر شيوعش افزوده مىشود اما بيمـارى در تمام طول سال مى تواند اتفاق بيافتد. هر كجا كه انسـان

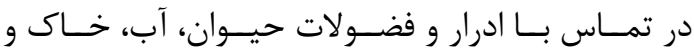
محيط آلوده قرار بخيرد، احتمال وقوع اين بيمارى وجود

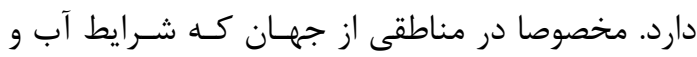
خاى آن قليايى باشد. بههمين علـت مسىباشـد كـهـ در سالهاى اخير در استانهــاى شـمالى ايــران بـهـ دليـل

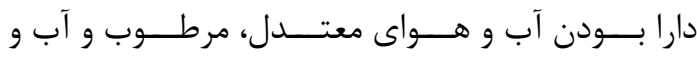
خاك قليـيـى مـوارد قابـل تـوجهى از بيمـارى انسـانى

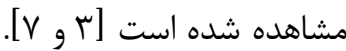

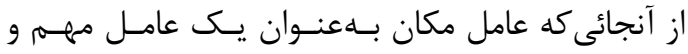

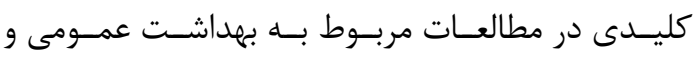

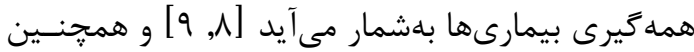

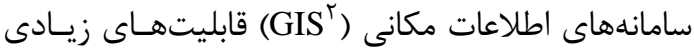

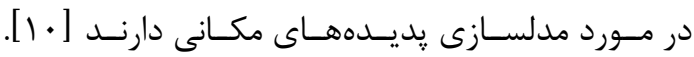

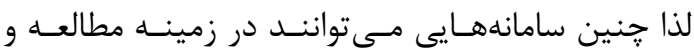

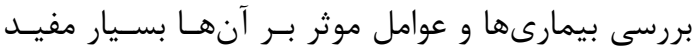

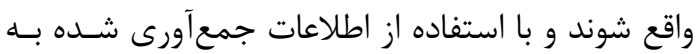

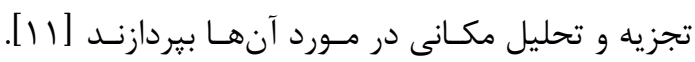

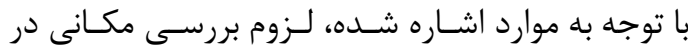

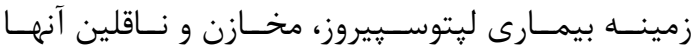

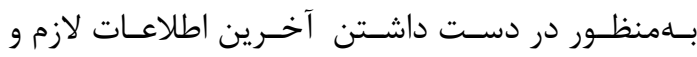

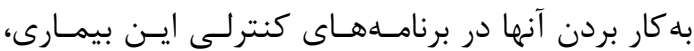

\footnotetext{
${ }^{2}$ Geographical Information System
}

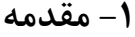

بيمارى لِيتوسيروز بهدليـل إيــدمى و شـيوع فزاينـده، مشكلى جهانى و مســـلهاى بـراى سـلامت عمـومى در

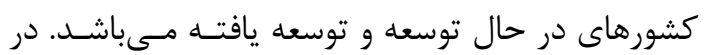
مناطق يرباران حاره و تحت حاره كـه اغلـب كشـورهاى

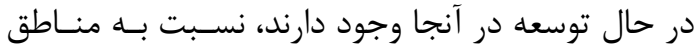

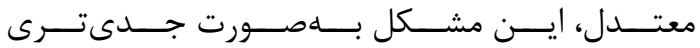

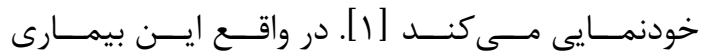
در تمام مناطق جهـان اتفـاق مسى افتــد امـا در منــاطق كرمسير يرباران شايعتر اسـت و در اغلـب ايـن منـاطق

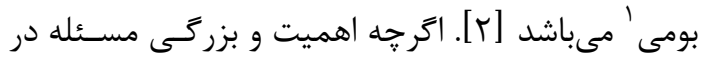

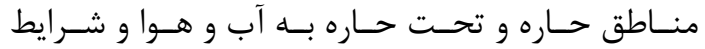
محيطى نسبت داده مىشود اما به احتمال زياد برخــورد

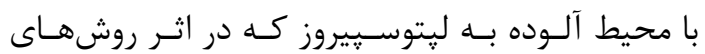
كشاورزى محلى، سكونت نامناسب و دفع غيربهداشـتى دئى زبالهها و مواد زايد كه همكى باعث ايجاد منـابع متعـدد

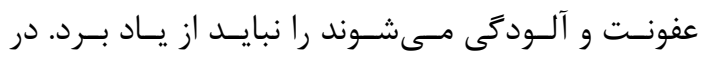

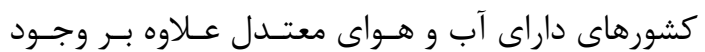

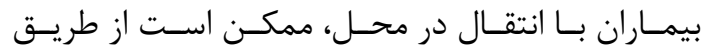
مسافرانى كه از مناطق حاره به اين مناطق مى آيند نيـز

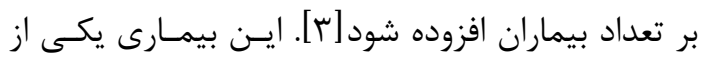
رايجترين و مخوفترين بيمارى عفـونى مشـترك ميـان

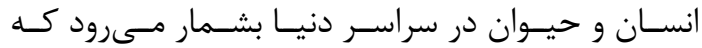

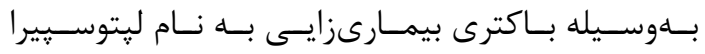

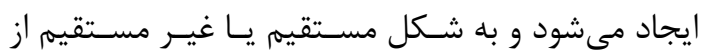

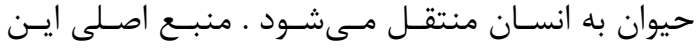

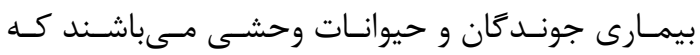

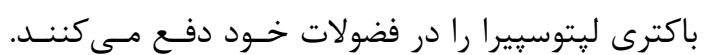

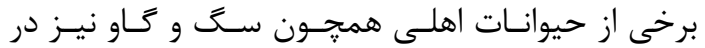

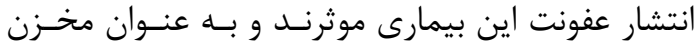

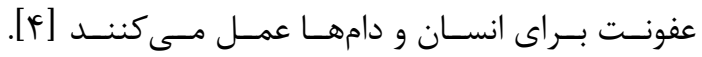
در سالهاى اخير، سير تحـولى بيمـارى لِيتوسـيـيروز از

${ }^{1}$ Endemic 


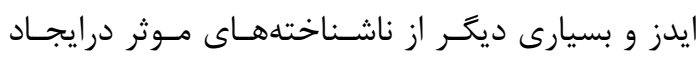

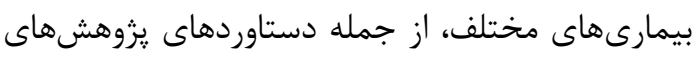
مكانى مرتبط با بيمارى در سراسر جهان و از نمونههاى

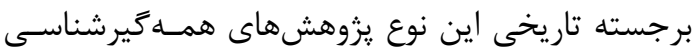

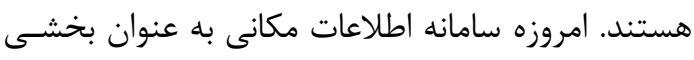
از فناورى اطلاعات توسط سازمانهاى مديريت بهداشت بهان

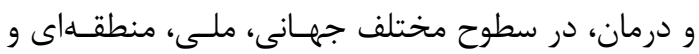

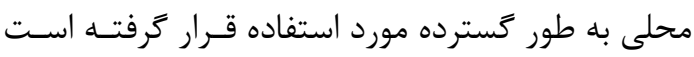

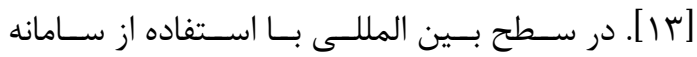

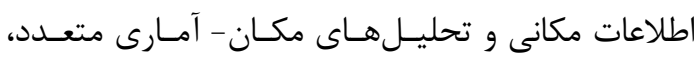

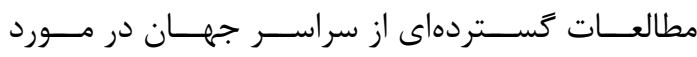

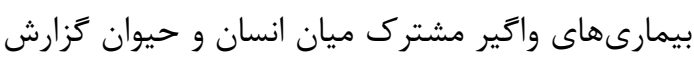

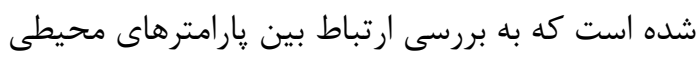

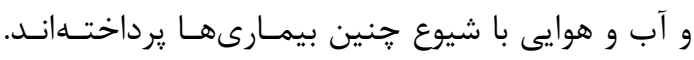

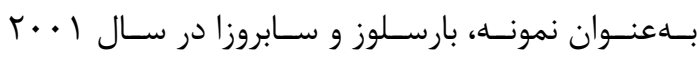

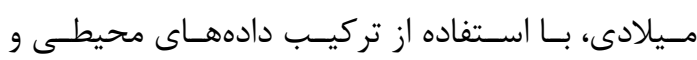

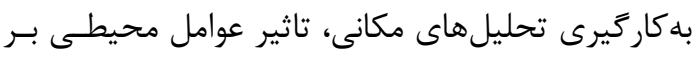

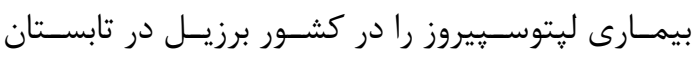

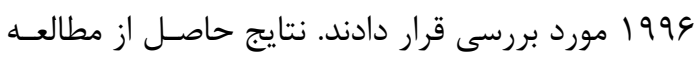

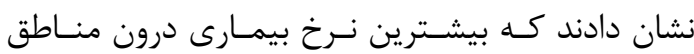

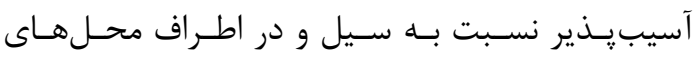

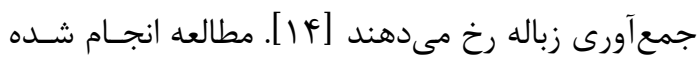

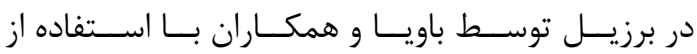

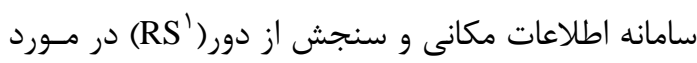

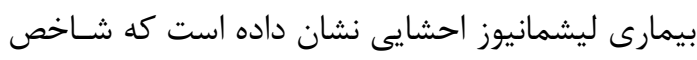

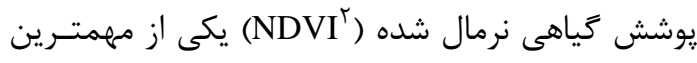

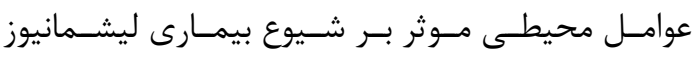

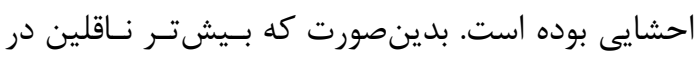

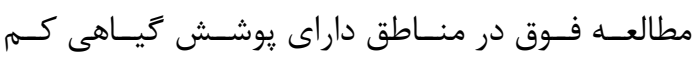

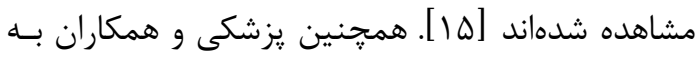

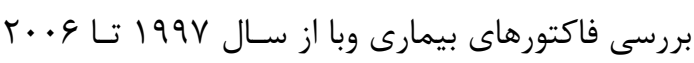

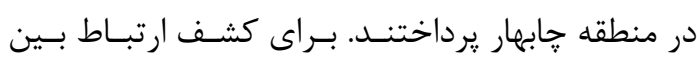

\footnotetext{
${ }^{1}$ Remote Sensing

${ }^{2}$ Normalized Difference Vegetation Index
}

ضرورى به نظر مى رسد. از طرفى عامل زمـان در وقـوع

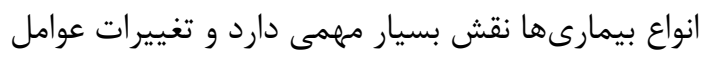

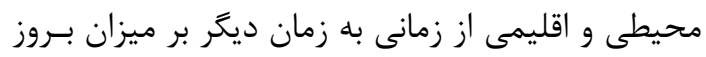

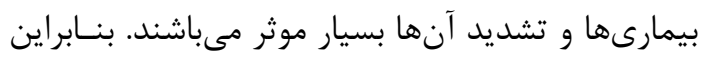

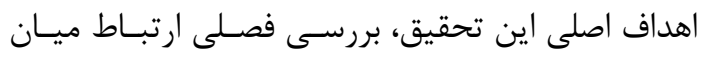

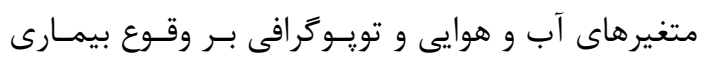

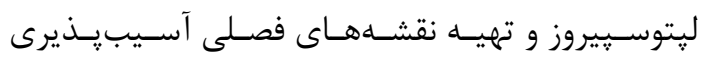

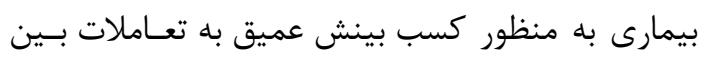

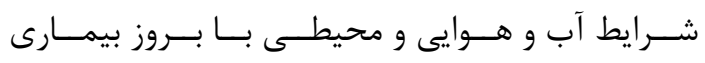

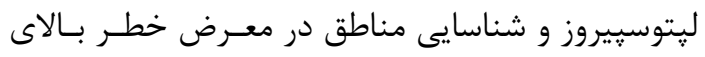
بيمارى در سطح بخشهاى اسـتانهـاى شـمالى ايــران

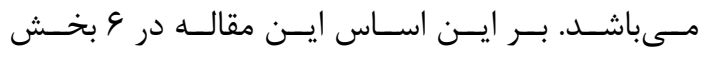

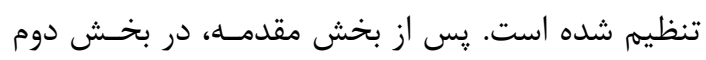
به بررسى مطالعات كذشته در زمينه بيمارى هاى واگيـر

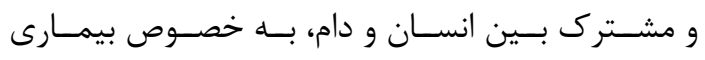

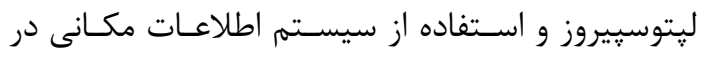

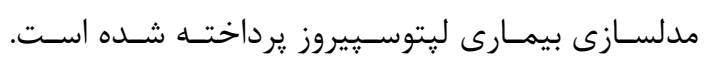

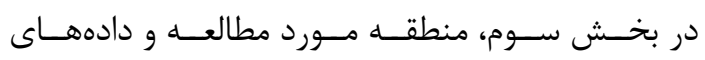

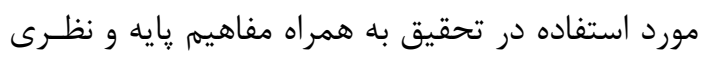
روشهاى مورد استفاده در تحقيق توضيح داده شدهاند.

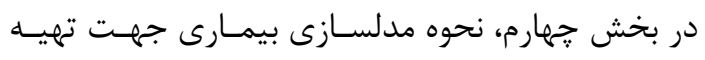

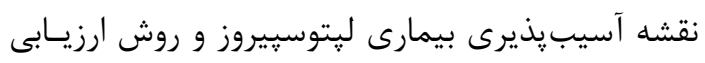

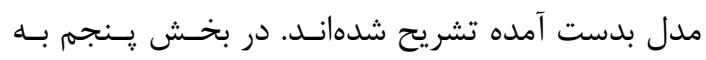

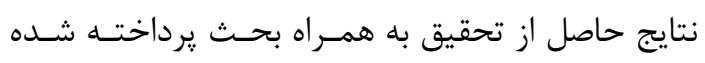

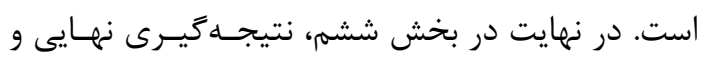
ييشنهاداتى براى تحقيقات آينده ارائه شدهاند.

\section{r- بيشينه تحقيق}

به دليل اهميت موضوع بيمارى در جهان از كذشتههاى

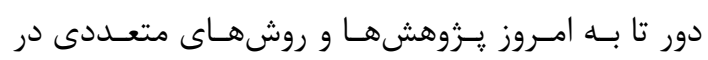

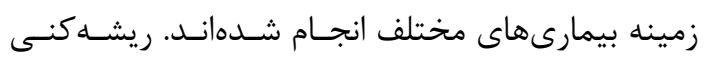

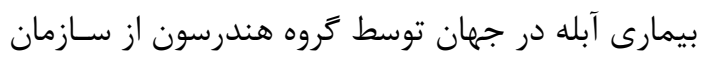

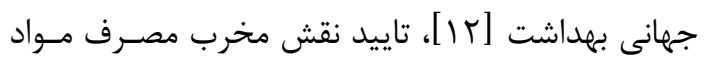

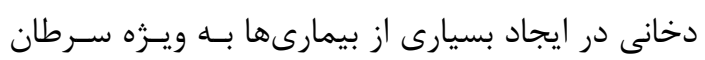

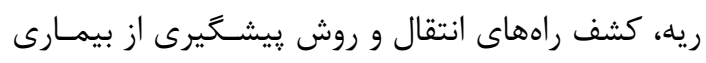




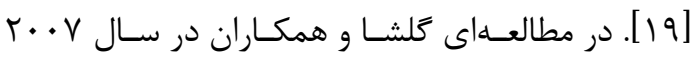

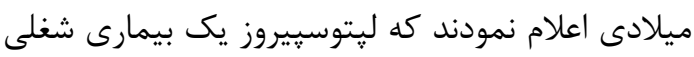

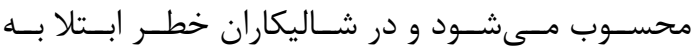

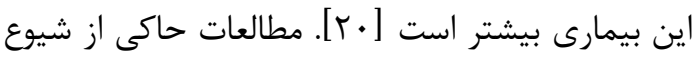

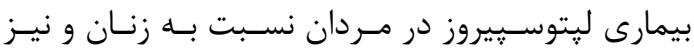
روستانشينان نسبت بـهـ شهرنشـينان هسـتند و بيـانكر اين نكته مى باشند كه شيوع بيمارى بـهـــور عمــده در

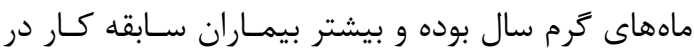

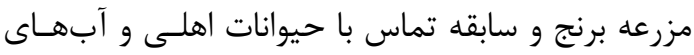

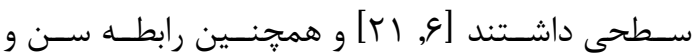

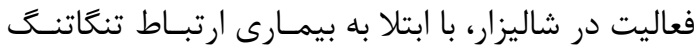

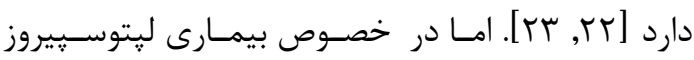
انسانى و استفاده از سامانه اطلاعـات مكـانى در تحليـل مكانى و مدلسازى بيمارى، تـاكنون مطالعـات كمسى در

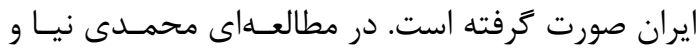

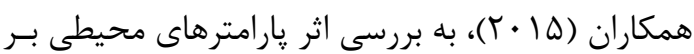

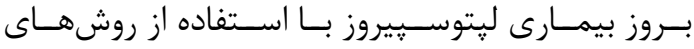

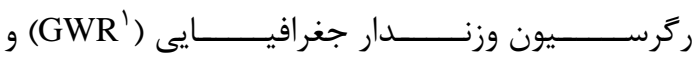
كمتـرين مربعـات معمـولى (OLS بهدست آمده از معيار ارزيابى R2، به خوبى برترى روش نسبت به OLS را بـهـليـل در نظــر حـرفتن اثـر

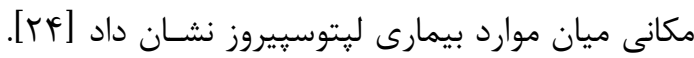

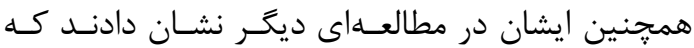
بيشترين موارد وقوع بيمارى در نواحى مركـزى اسـتان

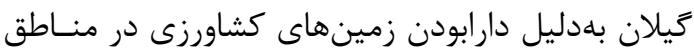
بست و با شيب كم و در ماههاى خرداد تا شهريور اتفاق

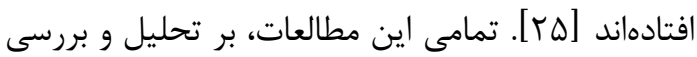

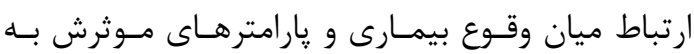

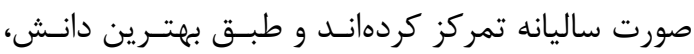

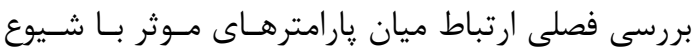

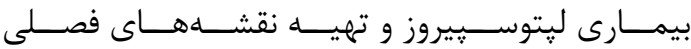
آسيب يذيرى بيمارى جهت تعيين مناطق بحر انس و در

${ }^{1}$ Geographically Weighted Regression

${ }^{2}$ Ordinary Least Square
وقوع بيمارى وبا و متغيرهاى آب و هــوايى از روشهـاى دادي

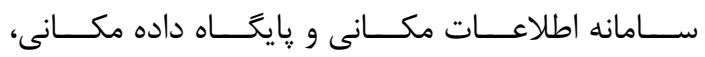
براى مدلسازى انتشار بيمارى از روشهاى خوشهبنـدى

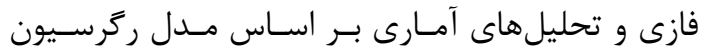

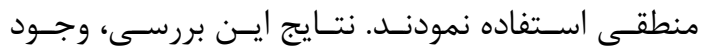

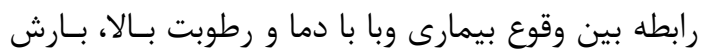

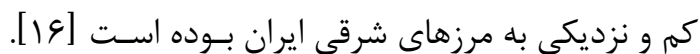

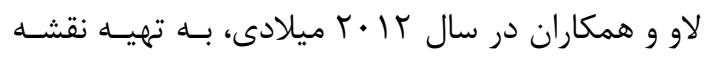
آسيبــــيرى بيمـارى لِّوسـيـيروز در آمـريكن سـاموا

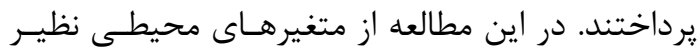

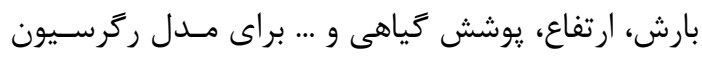

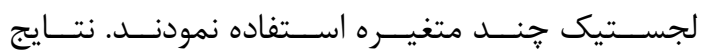
بهدست آمده حاكى از طبقهبندى صحيح أه درصـد از موارد كزارش شده در اين مطالعه بوده اسـت. از طرفى ارفى

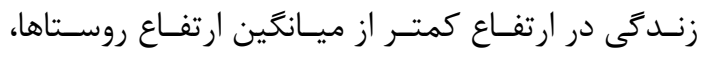

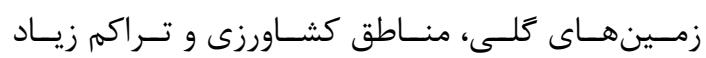
خوكدانى هاى منازل بيشـترين تـاثير را در ميـزان بـروزي

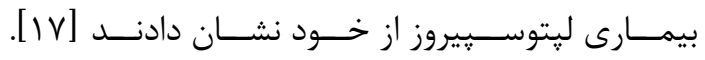

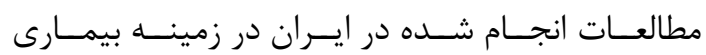

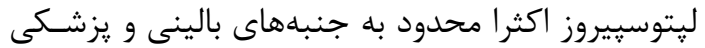
بيمارى بودهاند و بر شناخت ويزگى هاى فردى بيمـاران

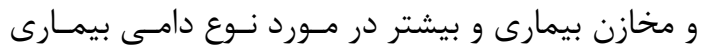
تمركز داشتهاند. بهعنوان نمونه، در مطالعهاى در بوشهر

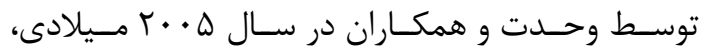

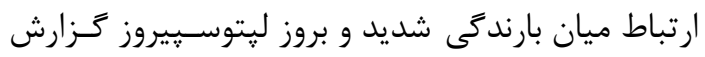
كرديد. جارى شدن سيلاب يس إز بارندگى براى برى رخداد

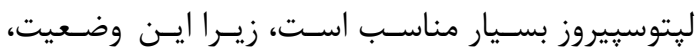

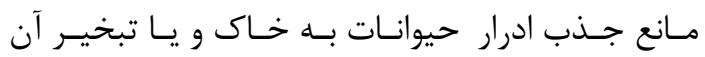

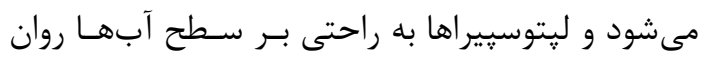

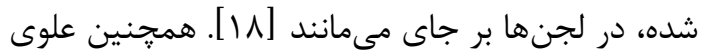

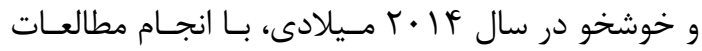

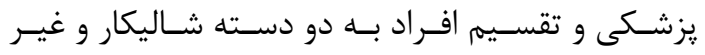
شاليكار دريافتند كه احتمال وقوع بيمـارى لِّتوســيروز در شاليكاران استان خوزستان مخصوصا جنسيت مرد و

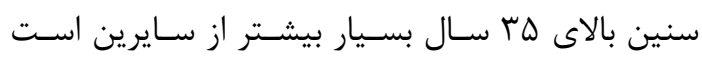


تعداد در مجموع به ترتيسب فراوانى، بل درصـد مـوارد

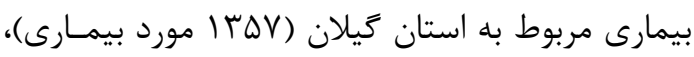

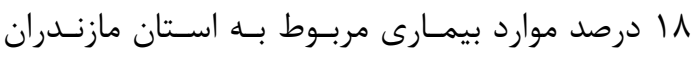

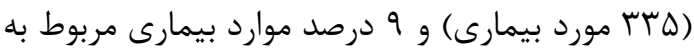

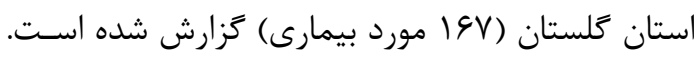

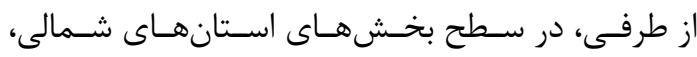
بيشترين موارد وقوع بيمارى به ترتيب فراوانس، متعلـق دراس

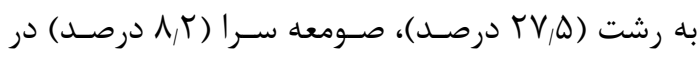

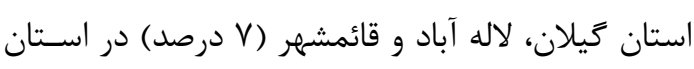

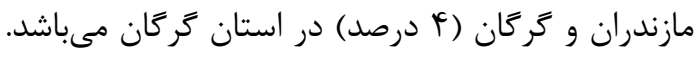

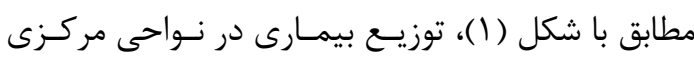

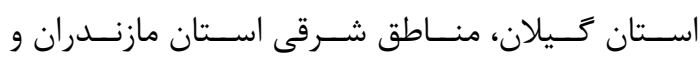

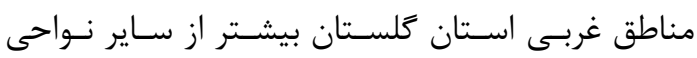

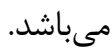
نتايج حاصل از بررسى هاى آمـارى مشـخص نمـود كـهـ

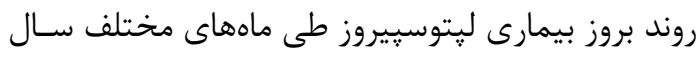

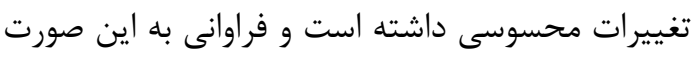

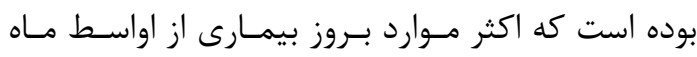

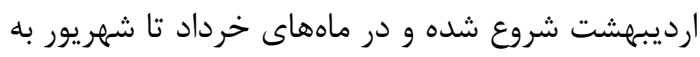

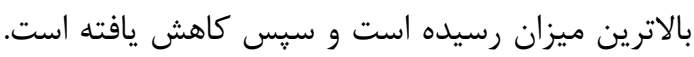

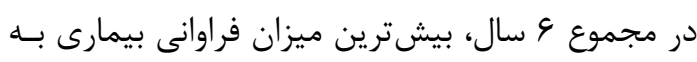

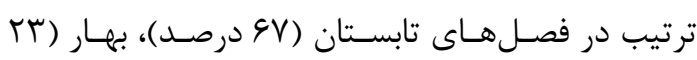

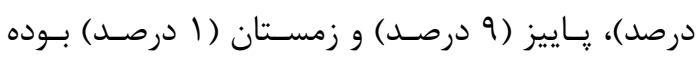

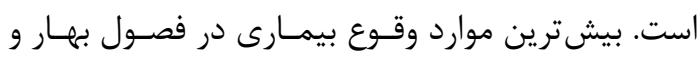

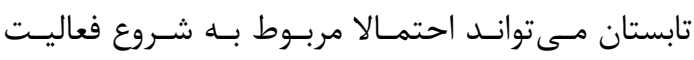

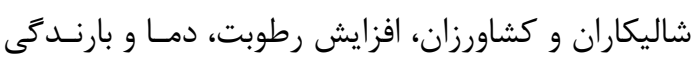

شديد باشد (شكل (r)).
معرض خطر بالاى بيمارى ليتوسـيـيروز در هـيجيج كـدام

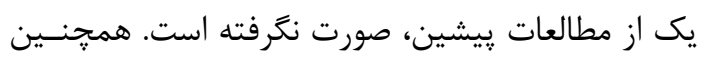

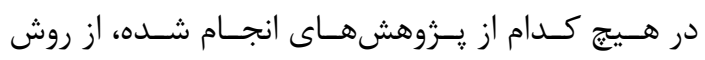

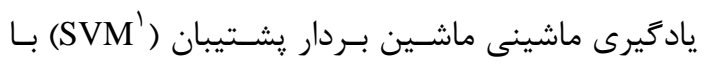

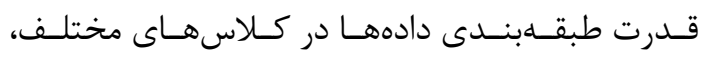
بلهنوان روشى براى تهيه نقشه آسيبذيذيرى بيمارىهـا استفاده نشده است.

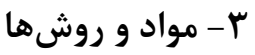
در اين قسمت از يزوهش علاوه بر اشاره به منطقه مورد

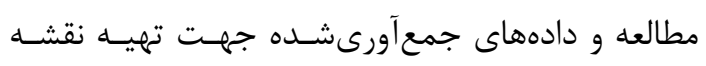

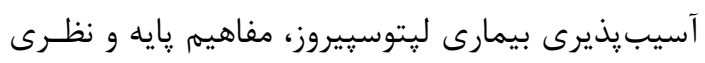

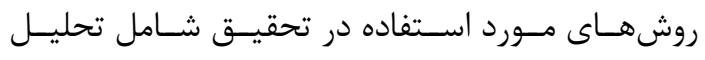

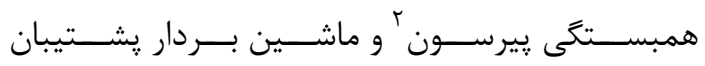

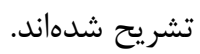

r-1- منطقه مورد مطالعه

استانهاى حاشيه درياى خزر شامل استانهاى كَيلان،

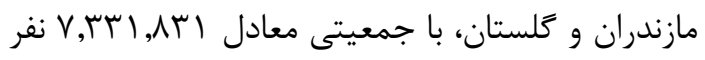

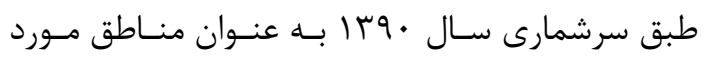

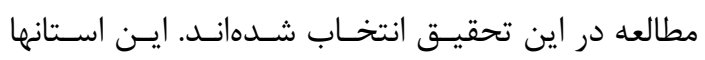

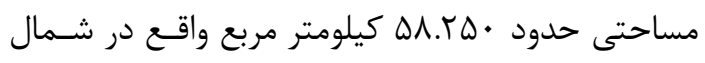

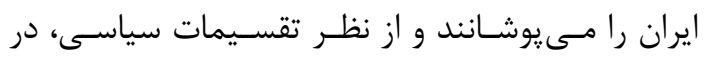

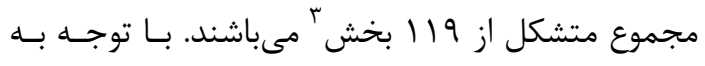

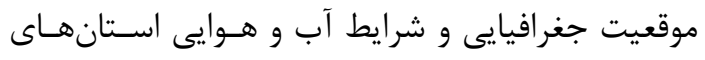

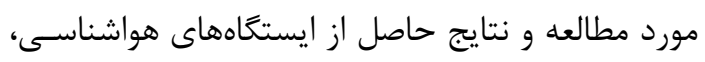

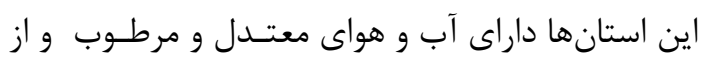

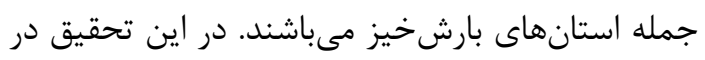

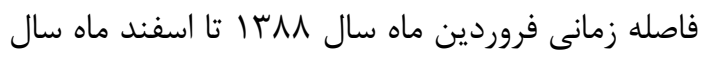

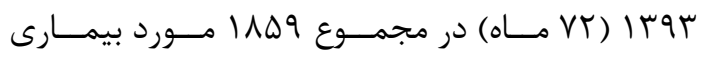

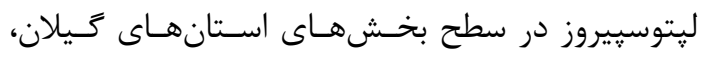

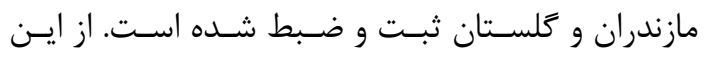

\footnotetext{
${ }^{1}$ Support Vector Machine (SVM)

${ }^{2}$ Pearson's correlation coefficient

${ }^{3}$ District
} 


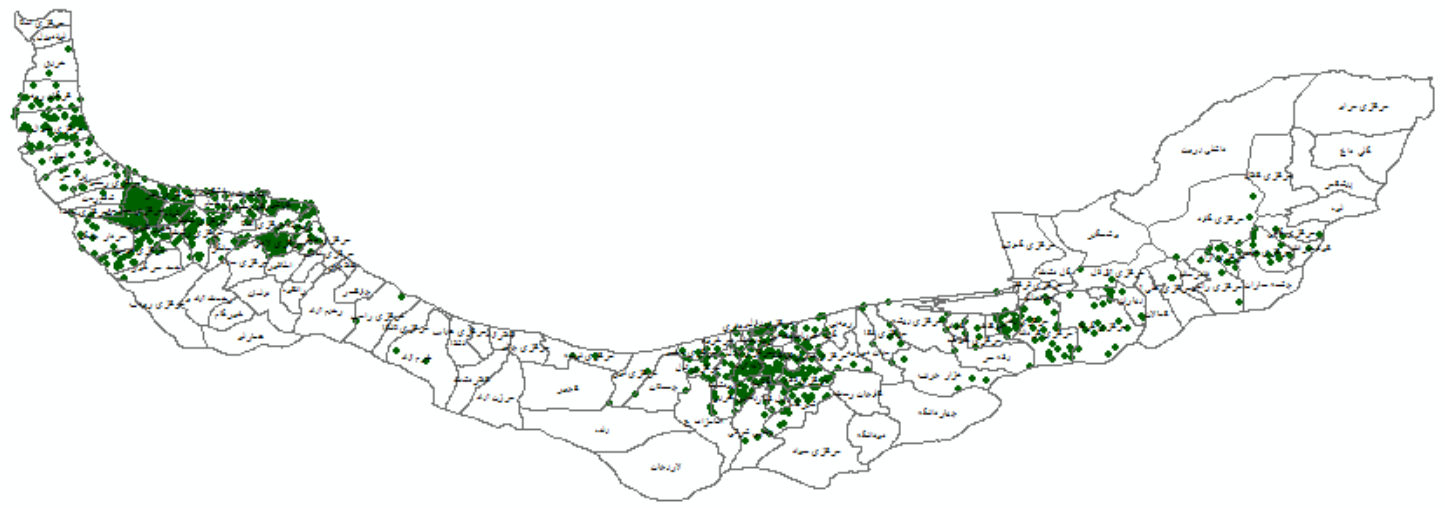

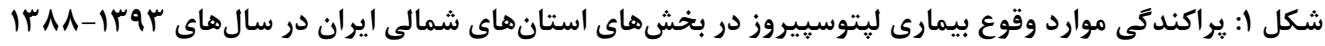

ليتوسييروز مربوط به جنسيت مرد بوده، اما اين بيمارى براى هر دو جنسيت زن و مرد تهديـد كنـــده اسـت. از

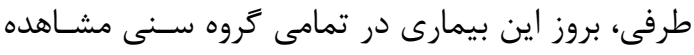

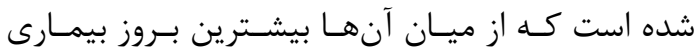

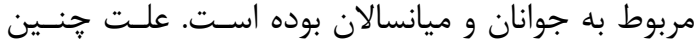
نتايجى ممكن است به دليل يوشـش كمتـر و تعـاملات اجتماعى و محيطىى بيشـتر مسردان نسـبت بــهـ زنـان و بيانگر خطر مواجهه در مشاغلى باشد كه مـردان بيشـتر در آن حضور دارند، به همين دليل بيمارى بين مـردان

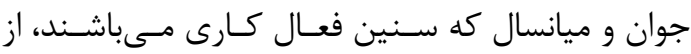
يسران و سالخوردَان شيوع بيشترى دارد (جدول (1)).

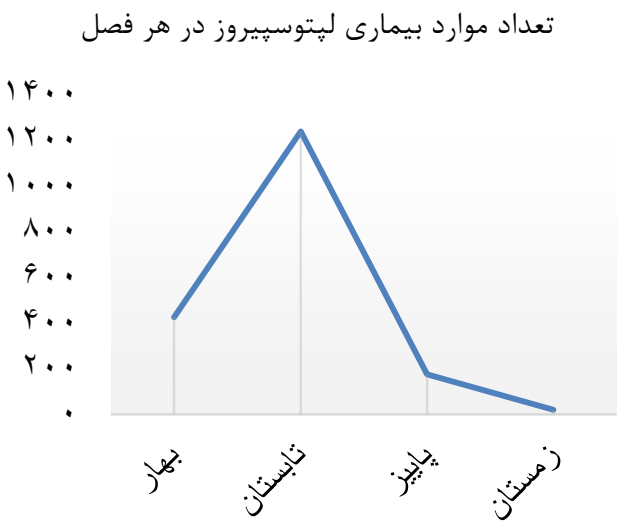

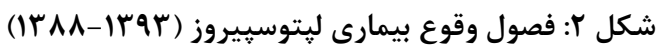
همجنين بررسى هاى آمارى مشخص نمود كه اخرجه در

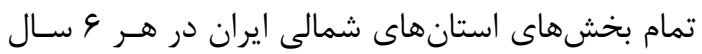

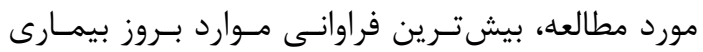

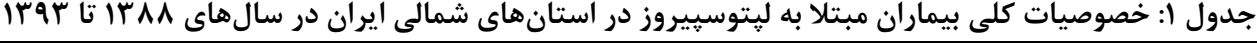

\begin{tabular}{|c|c|c|c|c|c|c|c|c|c|c|c|c|c|}
\hline \multirow{3}{*}{ 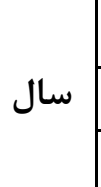 } & \multicolumn{13}{|c|}{ ويثَّى هاى جمعيت شناختى } \\
\hline & \multicolumn{4}{|c|}{ تعداد موارد وقوع بيمارى در هر فصل } & \multicolumn{7}{|c|}{ كروه سنى } & \multicolumn{2}{|c|}{ جنسيت } \\
\hline & بهار & تابستان & ياييز & 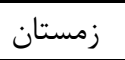 & $\cdot-\varphi^{f}$ & $\Delta-1$. & $\mid 1-14$ & $\mid Q-T^{\prime}$ & $r \Delta-r^{K}$ & $r \Delta-\Delta \Delta$ & ${ }^{+} \Delta \varphi$ & مرد & زن \\
\hline IrNA & pq & rit & אי & $\cdot$ & 1 & r & 1 & r & $\Delta r$ & $I V \wedge$ & tr & rIT & NT \\
\hline 1149 & 11. & Fr. & r. & $r$ & . & . & 1 & $\Delta \varphi$ & VA & raq & 99 & 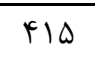 & $14 \lambda$ \\
\hline $11 \%$. & FT & 19. & TF & $\Delta$ & - & . & . & $\pi$ & Fa & IrV & re & $I Q V$ & $V^{c}$ \\
\hline $\mid 14$ & $\Lambda$. & $|r|$ & $4 q$ & r & - & . & $r$ & 19 & $i_{1}$ & IrV & rF & 114 & $4 q$ \\
\hline Irqr & 9. & I & re & 9 & . & . & $r$ & $r T$ & Ff & 18 & $T^{F}$ & $I V F$ & 19 \\
\hline س & $\Lambda \Delta$ & 191 & rd & $r$ & . & . & 1 & 19 & is & $I V F$ & rV & $1 \wedge r$ & 91 \\
\hline مجموع & FYG & גזו & $I V \Delta$ & $r$. & 1 & $r$ & $\Lambda$ & 109 & $r \cdot v$ & $110 \Delta$ & TYV & ITKG & Wr \\
\hline
\end{tabular}


از سازمان هواشناسى ايران در طى بازه زمانى مورد نظر

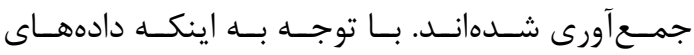

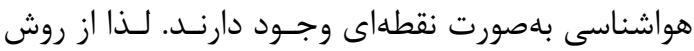

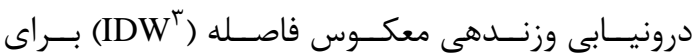
داشتن سطحى يِيوسته استفاده شده است. با اسـتفاده

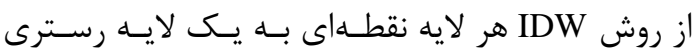

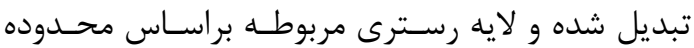
منطقه مورد مطالعه برش داده شده است. ســــ بـ بـراى

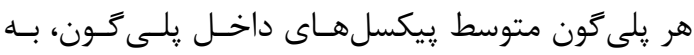

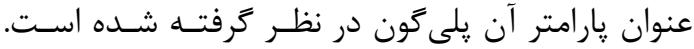

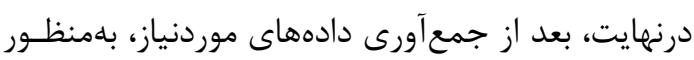

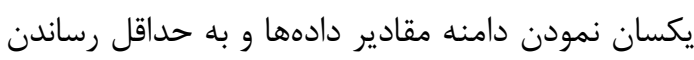

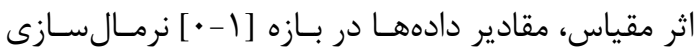
شدهاند. سيس بهمنظور به كاركيرى هر كـدام از دادهـــا

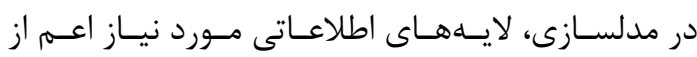
نقشههـاى ارتفـاعى، شـيب، يوشـش كيـاهي، ميـانكين دماى هوا، ميانكَين رطوبت هوا، مجموع بـارش سـاليانه، تعداد روزهاى يخبندان و نرخ شيوع بيمارى لِيتوسبيروز

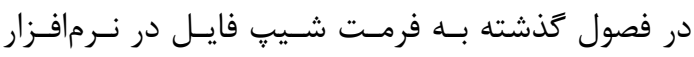
ArcGIS 10.2.2

\section{ץ-ץ- تحليل همبستَّى ييرسون}

رابطه همبستخى يِيرسون به بررسى ارتباط ميـان دو يـاـ جند متغير ترداخته و ضريب آن را محاسبه مسىنمايسـد.

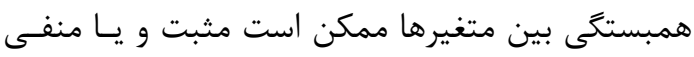

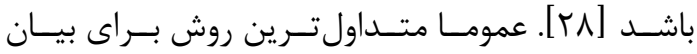

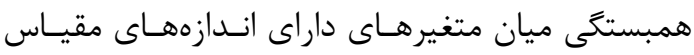

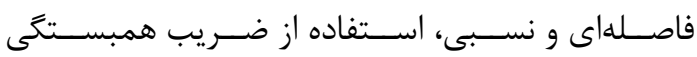

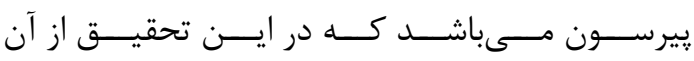
(r)

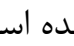

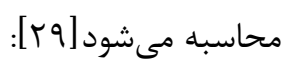
$\mathrm{r}_{\mathrm{x}, \mathrm{y}}=\frac{\sum x * y}{\mathrm{~N}^{*} \mathrm{~S} \mathrm{~S}^{*} \mathrm{Sy}}$ (T) رابطه در رابطـهـهـــوق،

\footnotetext{
${ }^{3}$ Inverse distance weighting
}

\section{ץ-ץ- جمع آورى و آمادهسازى دادهها} در اين يزوهش اطلاعات مربوط به ميزان شيوع بيمارى

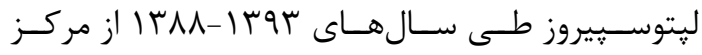

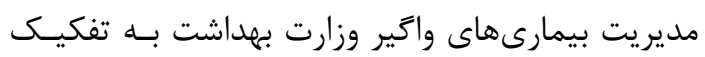

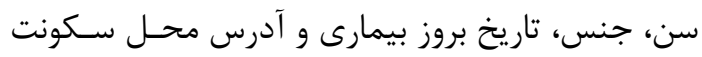

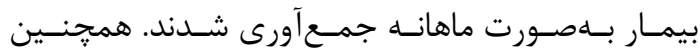

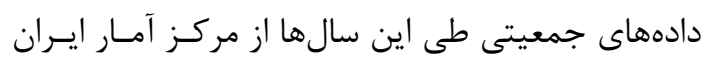
بلهدست آمدهاند. سيس با استفاده از دادههاى جمعيتى إنى

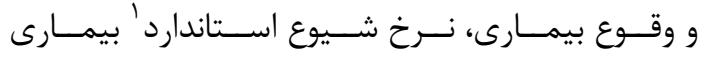
ليتوسيّروز طبق رابطه ( (1)، محاسبه كرديد. رابطه (1)

\section{نرخ شيوع =

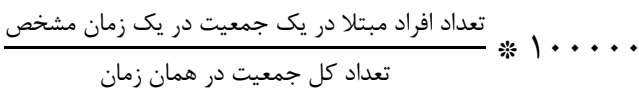

همجنين به دليل تاثيركذارى بالايى كه عوامل محيطى نمان بر شيوع بيمارىها دارند، لذا متغيرهاى بوشش تيـاهي،

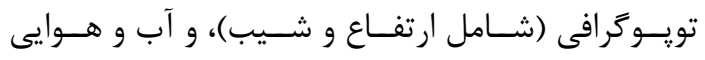

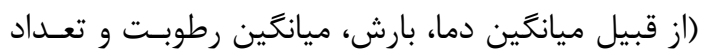
روزهاى يخبندان) كه بيشترين استفاده را در مطالعـات

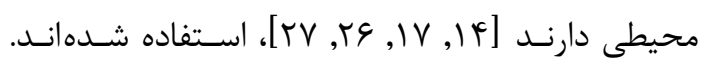
بهمنظـور بررسى اثـر يوشـش كيـاهى بـر روى شـيوع

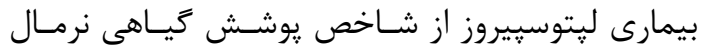

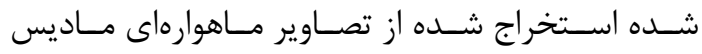

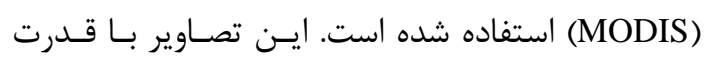

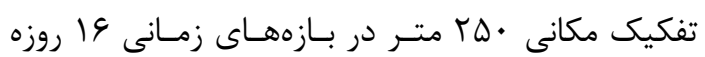

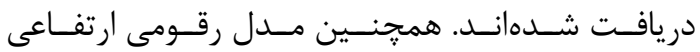

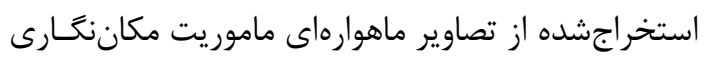

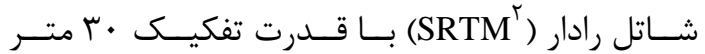

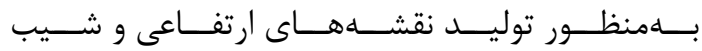

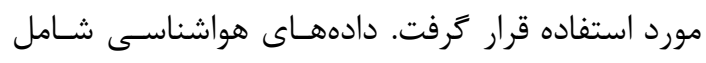

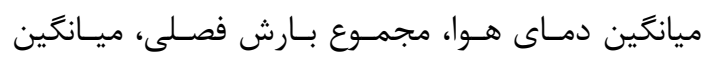
رطوبت هوا و تعداد روزهاى يخبندان به صـورت ماهانسه

${ }^{1}$ Standardized Incidence Rate (SIR)

${ }^{2}$ Shuttle Radar Topography Mission (SRTM) 
بـا اسـتفاده از نتــايج تـابع PCA، فـرض مسىشـود كــه

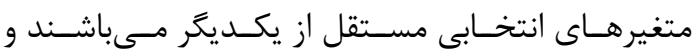
رابطه همخطى ميان آنها برقرار نيست. با توجه به اينكه در اين تحقيق، همبستخى بين متغيرهاى تويـوگرافى و

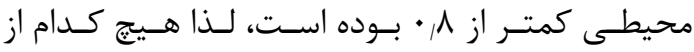

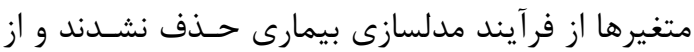

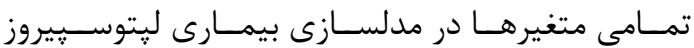

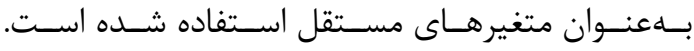

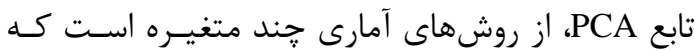
مى توان از آن براى كاهش تعداد متغيرها و تفسير بهتـر

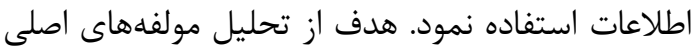

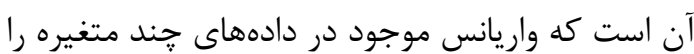

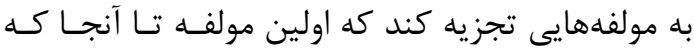
ممكن است علت بيشترين واريانس موجـود در دادههــا

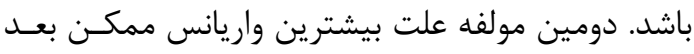

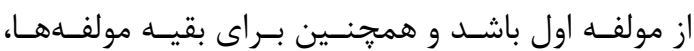

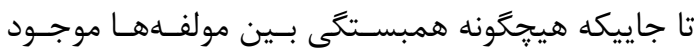
نباشد. با اعمال اين روش، متغيرهـاى ورودى اوليـهـ بــهـ مولفههاى جديد و بدون همبستتى تبـديل مسى شـوند؛

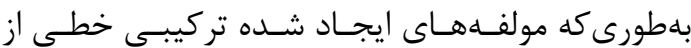

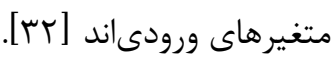

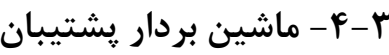

ماشـين بــردار ريشـتيبان بــهنــــان يـــ روش موفـق

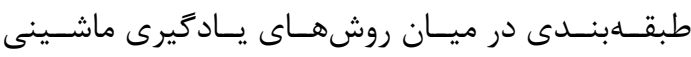

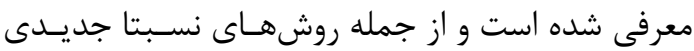
است كه در سال هـاى اخيـر كـارايى خـوبى نســبت بــه روش هاى قديمى تر براى طبقهبندى از جمله شبكه هاى

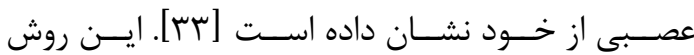

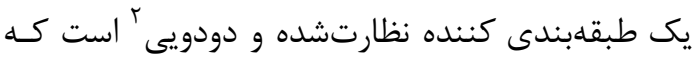
علاوه بر كلاسهبندى و تشخيص الكوها، براى ييشبينى

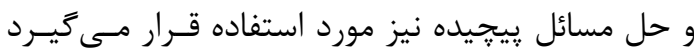

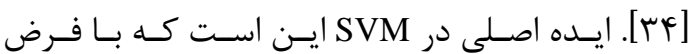

\footnotetext{
${ }^{2}$ Binary
}

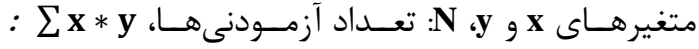
مجموع حاصـلـضـرب تفاضـل مقــادير از ميـانخين، Sx:

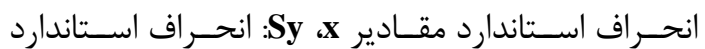
مقادير y مىباشد. مقدار ضريب همبستخى ييرسون بين

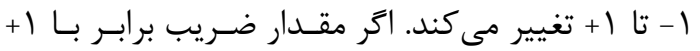
باشد، همبستخى مثبت كامل را نشـان مـى مهــد و اخـر برابر با ا - باشد، نشان دهنده همبستكى كامـل و منفـى مئى است. در حالت كلى، مقدار ضـريب همبسـتخَى در بـازه

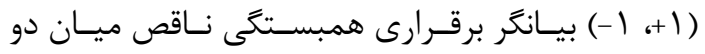

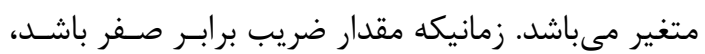

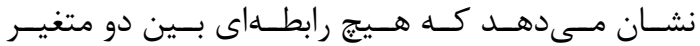

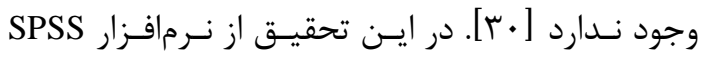

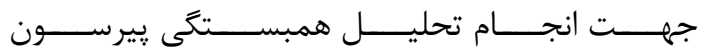

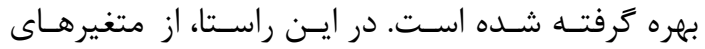

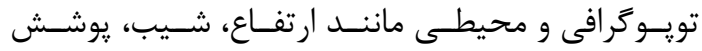

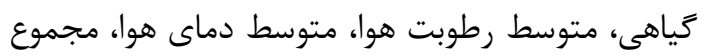

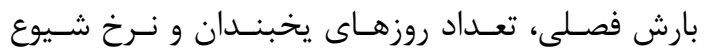

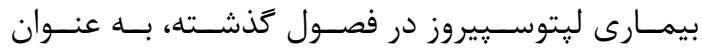

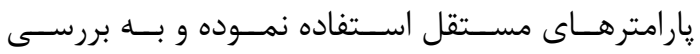

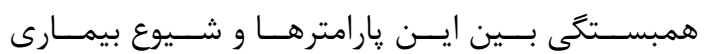
ليتوسيّيروز در فصل مورد نظر به عنوان يارامتر وابسـته،

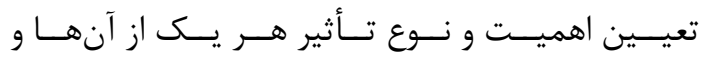
مشخص نمودن متغيرهـايى كـهـه بيشـترين تـاثير را بــر وقوع بيمارى دارنـد بـا اسـتفاده از تحليـل همبسـتخى مئى ييرسون يرداخته شده است (لازم به ذكر اسـت كـهـ بـهـ

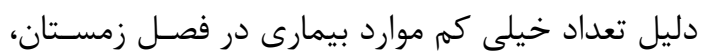

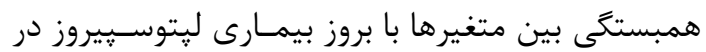
فصــول بهـار، تابسـتان و يــاييز بررسـى شـده اسـت).

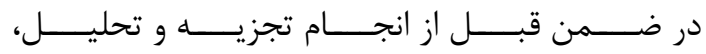
ميزان همبستخى بين متغيرها با استفاده از تابع تحليـل

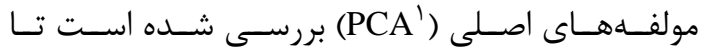
متغيرهايى كه كمترين همبستخى (همبستخى كمتـر از

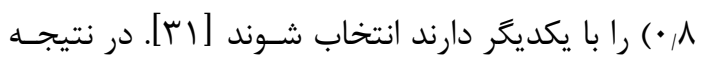

${ }^{1}$ Principal Component Analysis 
يكى از مزاياى ماشين بردار رشتيبان محدود نبــودن آن

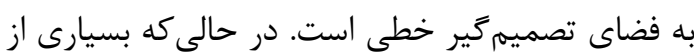

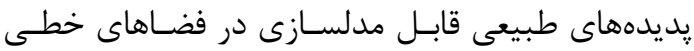

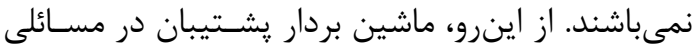

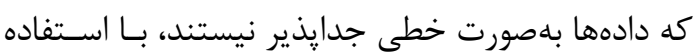

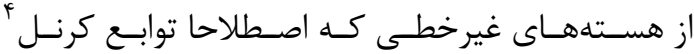

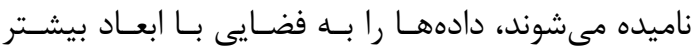

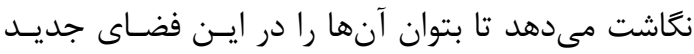
بهصورت خطى جدا نمود [عَ] (شكل (ه)).

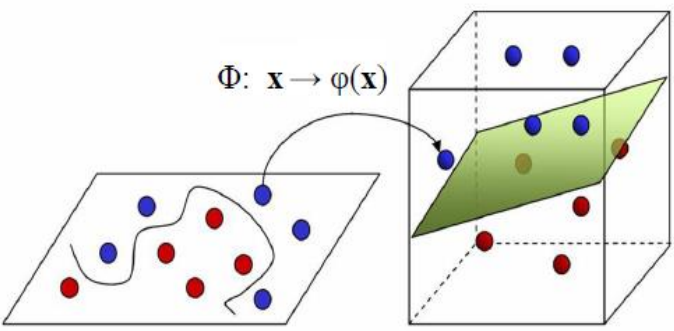

شكل ه: استفاده از تابع كرنل براى نكاشت به فضايى با

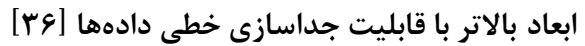

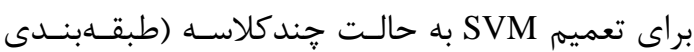

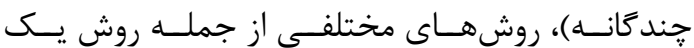

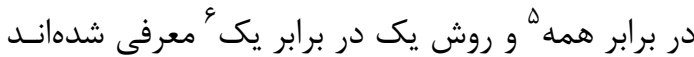

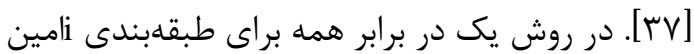

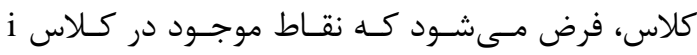
بلهعنوان نمونـهـهـاى مثبـت و تمـامى نقــاط موجــود در

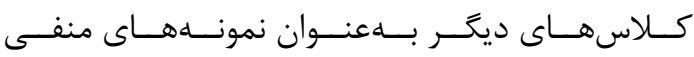
در نظر كرفته شوند. زمانيكه كه المانهاى ايـن كـلاس مشخص شدند. كلاس بعدى را در نظر كرفته و مجـدها مراحل تكرار مىشود. اين كار تا زمانى كه تمام كلاسها طبقهبندى شوند، ادامه بِيدا مسى كنــد. بنـابراين در ايـن

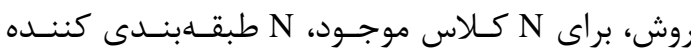

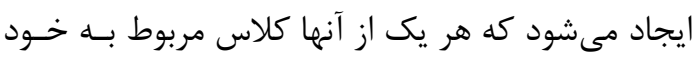

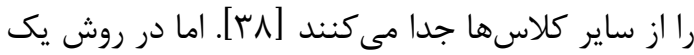
در برابر يك، الكوريتم به ازاى هر جفت كـلاس موجـود آدادي

\footnotetext{
${ }^{4}$ Kernel Function

${ }^{5}$ One against all

${ }^{6}$ One against one
}

جدايذيرى كلاسها از هـم، ابرصـفحاتى ' كـهـ قـادر بـهـ

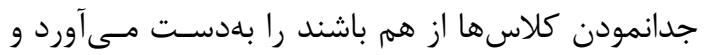

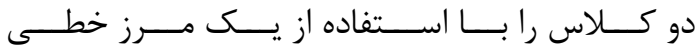

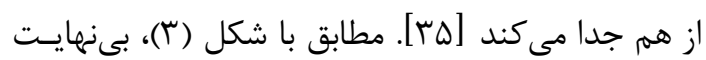

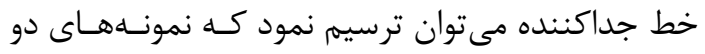

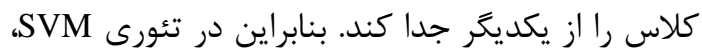

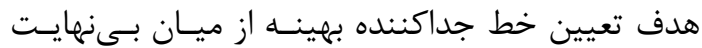
خطوط جداكنده مىباشد.

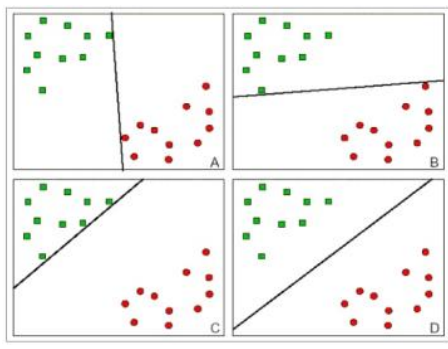

شكل r: مرزهاى مختلف در جداسازى دو كلاس [هـ]

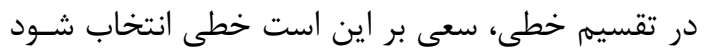

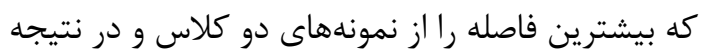
خطاى تعميم كمترى داشته باشد. اين فاصله در تئورى

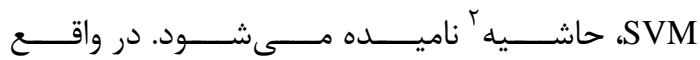
ماشين بردار يشتيبان ابر صفحهاى ايجاد مسىكنـد كـهـ

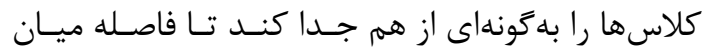

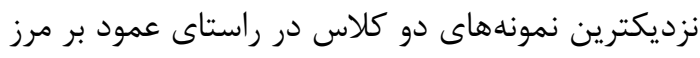

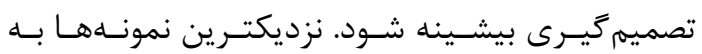

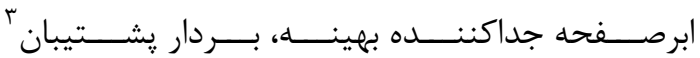

ناميده مىشود [بr] (شكل (\&)).

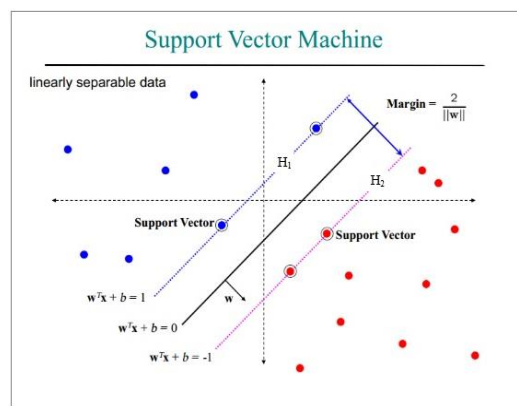

شكل f: ابرصفحه جداكننده خطى در فضاى خطى [هـ]

\footnotetext{
${ }^{1}$ Hyperplane

${ }^{2}$ Margin

${ }^{3}$ Support Vector
} 


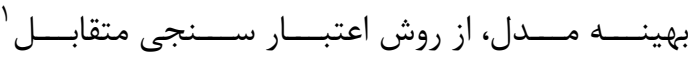

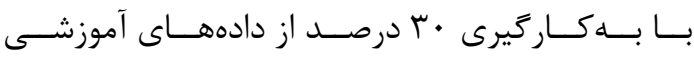

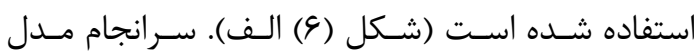

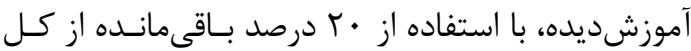

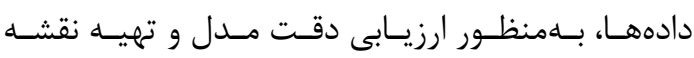

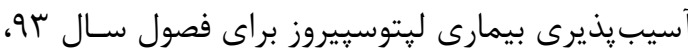

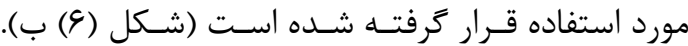
همجنين در اين تحقيق، با توجه به تعداد كم كلاسهـا

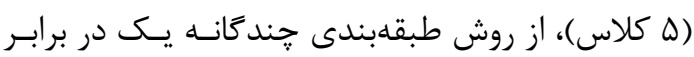

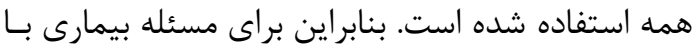

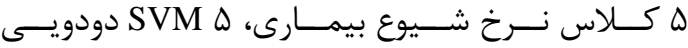

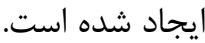
در اين يزوهش بهمنظور ارزيابى مدل SVM از منحنسى

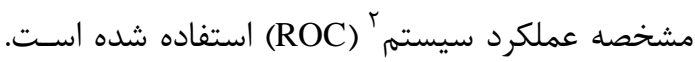

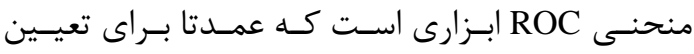

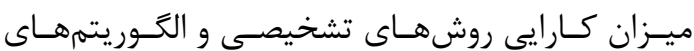

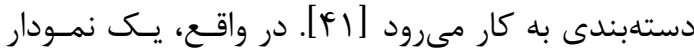

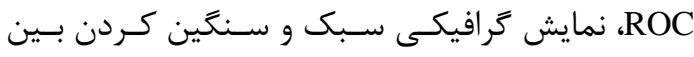

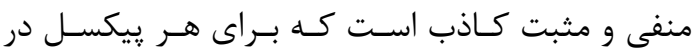

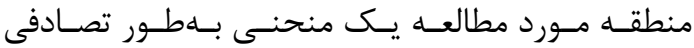

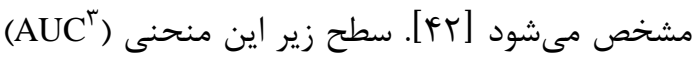

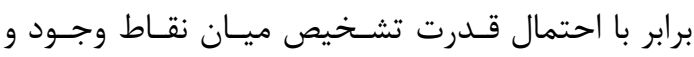

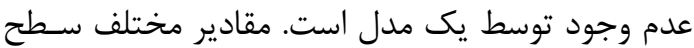

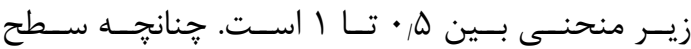

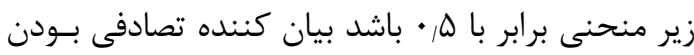

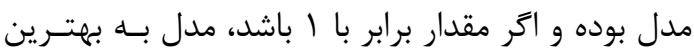

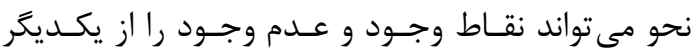
تفكيك نمايد. سطح زير منحنى بين V|, تا م/ • بيـانكر

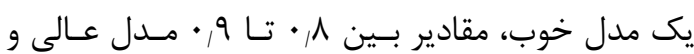

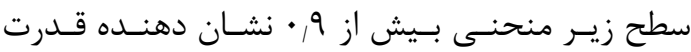

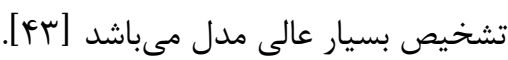

\footnotetext{
${ }^{1}$ Cross- validation

${ }^{2}$ Receiver Operating Characteristic (ROC)

${ }^{3}$ Area Under the Curve (AUC)
}

آموزش داده مىشود. بنابراين بـراى N كـلاس موجـود، بهتعداد N(N-1) طبقهبندى كنينده ايجاد مسىشـود كـهـ

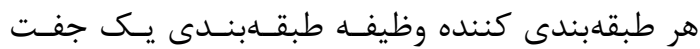

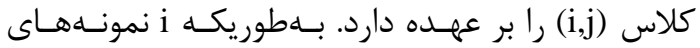

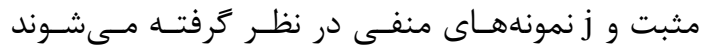

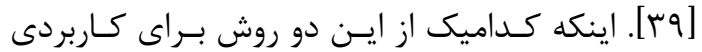

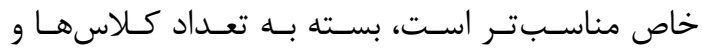

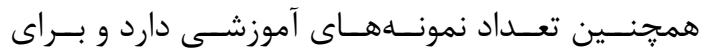

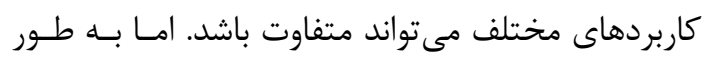

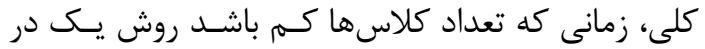
برابر همه روش مناسبترى است. اما زمـانى كـه تعـداد

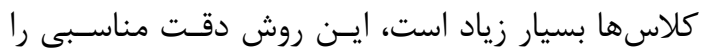

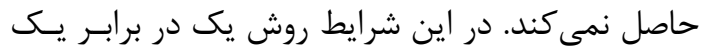

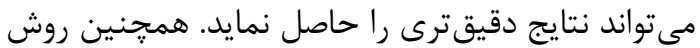

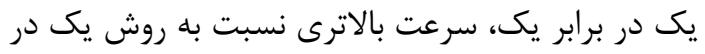

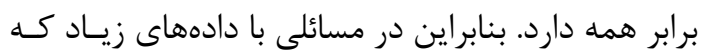

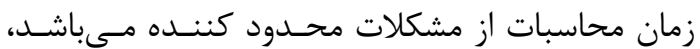

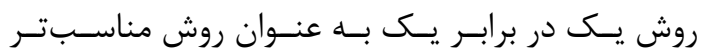

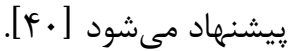
r-ه - مدلسازى و ارزيابى

در ايــن تحقيـق، بــه منظــور آمـوزش مــدل SVM، ابتدا دادههاى مربوط به وقـوع بيمـارى لِيتوسـيِيروز در

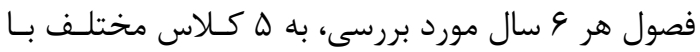

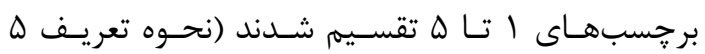
كلاس بدين صورت بوده است كه دادههاى در محـدوده

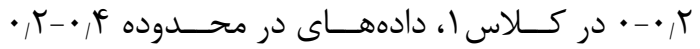

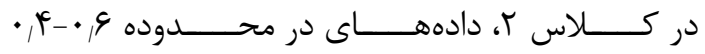

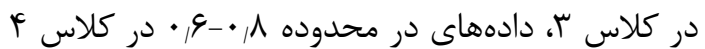

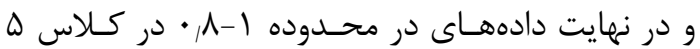

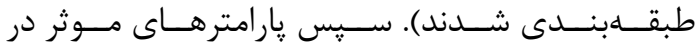
وقوع بيمارى بههمراه برجسبهاى كلاس وقوع بيمـارى

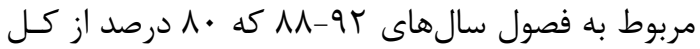

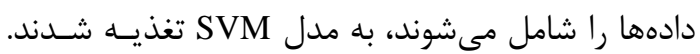

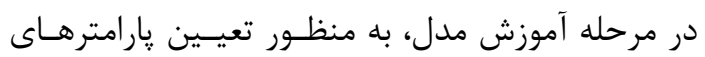




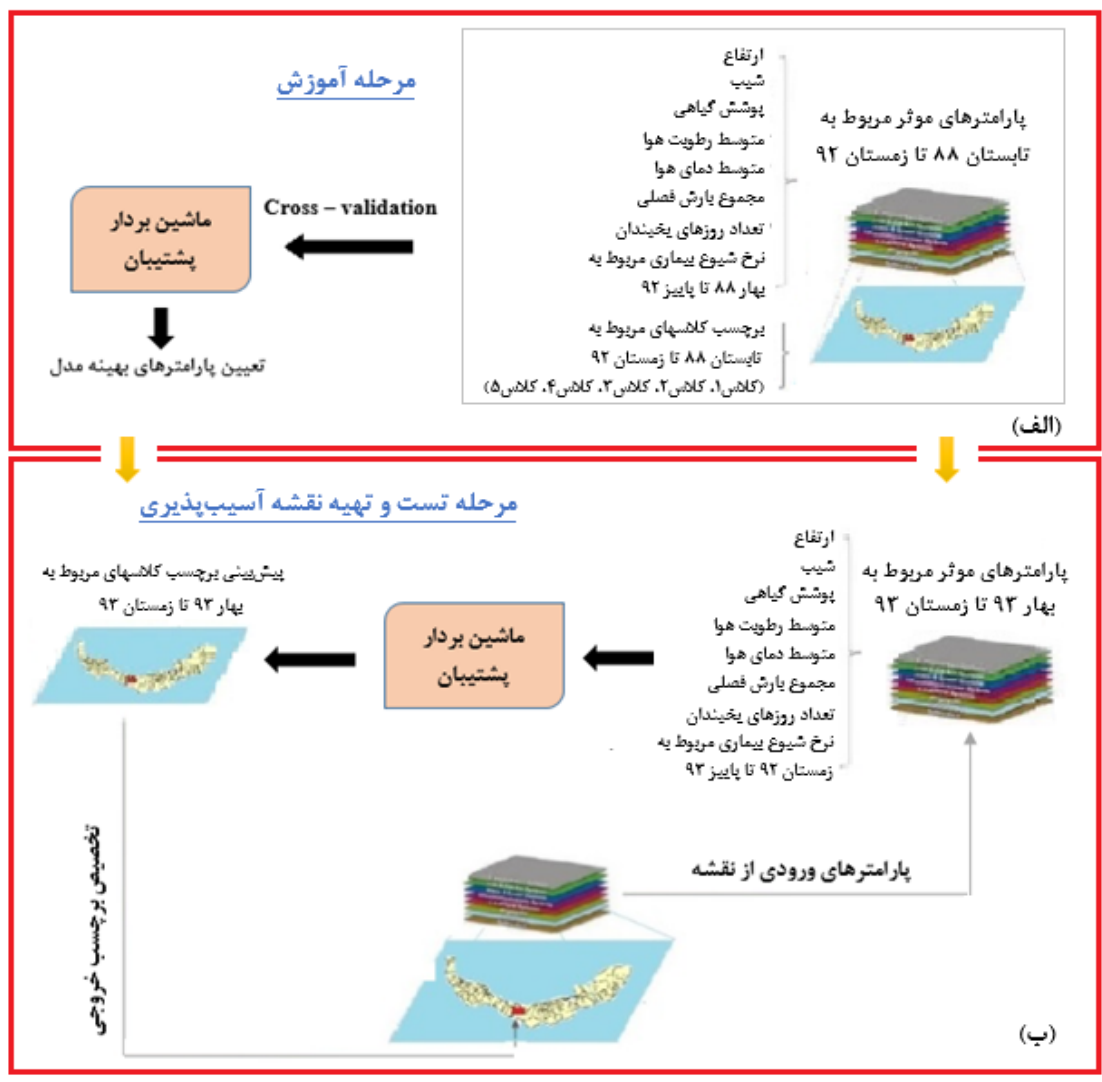

شكل و: فر آيند آموزش مدل SVM

نشان مى دهـــــ و نشـان دهنـــه ايـن مطلـب اسـت كـهـ

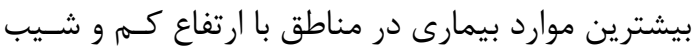

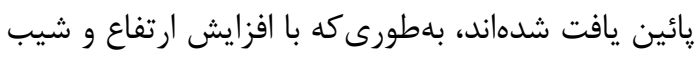

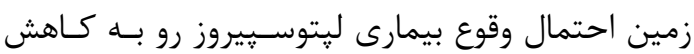

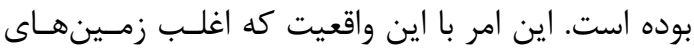

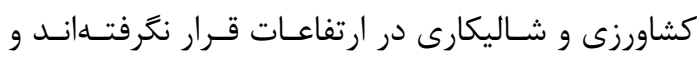
بيشتر در مناطق پست با شيب كم حضور دارند، منطبق

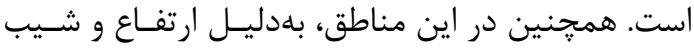

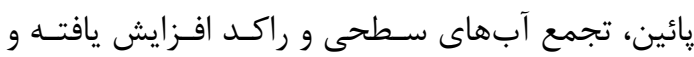

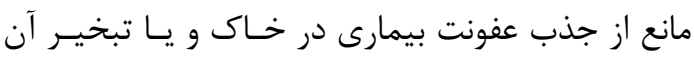

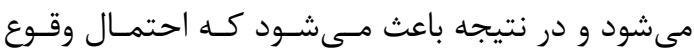

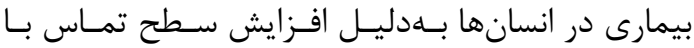
عفونت بيمارى، بيشتر شود (شكل (^)).

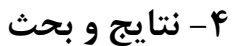

مقايسه محل وقوع موارد بيمارى ليتوسييروز در 9 سال

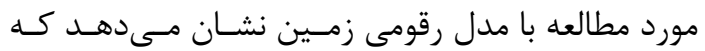
بيش از هو درصد از موارد بروز بيمارى ليتوسـيِيروز در

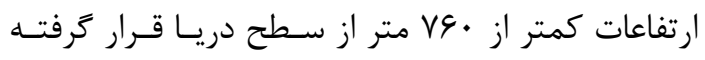

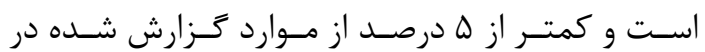

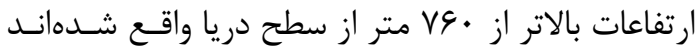

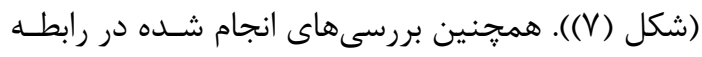

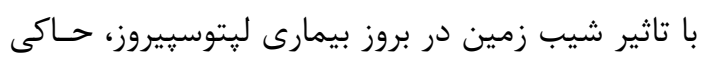

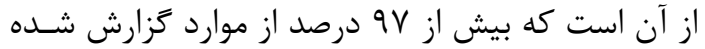

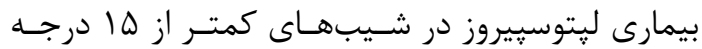

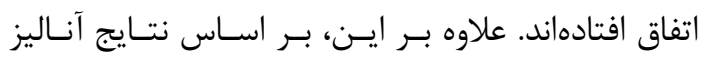

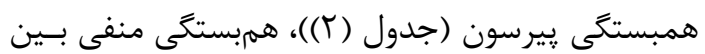
ارتفاع و شيب با بروز بيمارى ليتوسـيِيروز وجـود دارد و

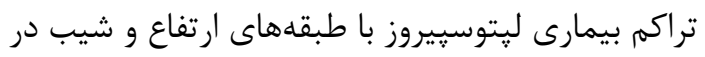

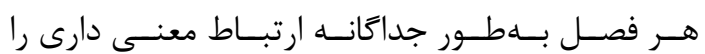


همبستخى ضـعيف بــين ايـن متغيرهـاو بـروز بيمـارى

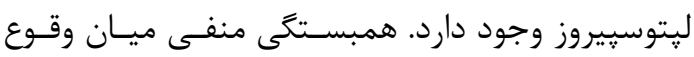
بيمارى و تعداد روزهاى يخبندان مىتواند به ايـن علـت دئس باشد كه در آب و هواى سرد و يخبندان، احتمال ادامسه حيات، تكثير و انتقال باكترى و عفونت بيمارى كـاهش

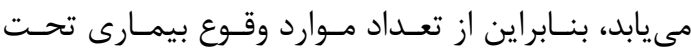

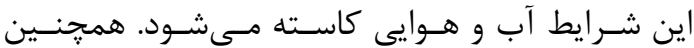
همبستكى منفى ميان يوشش كياهى و وقوع بيمارى را

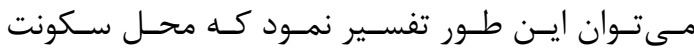

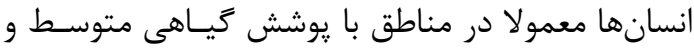
كم و حتى بدون يوشش گياهى (مناطق شهرى) واقع بـ

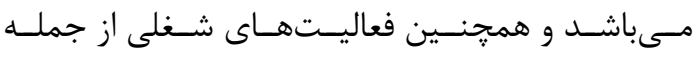

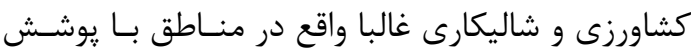

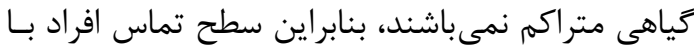

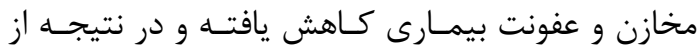
تعداد موارد بيمارى در مناطق با يوشش كياهى متــراكم

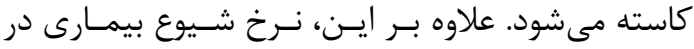

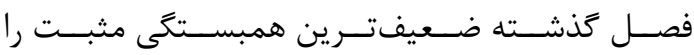

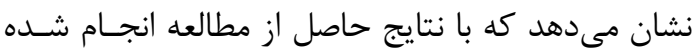

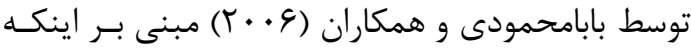

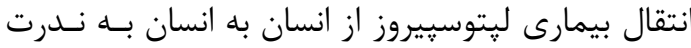

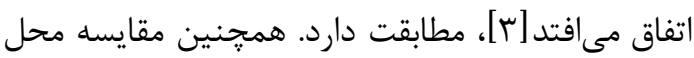
وقوع موارد بيمارى ليتوسيروز با شرايط آب و هـوايى و

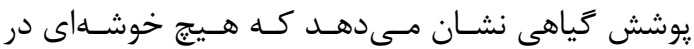

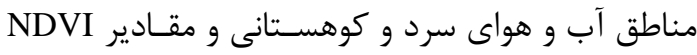
بالاتر موجود نبوده است. در حالى كه منــاطق بـا مـوارد

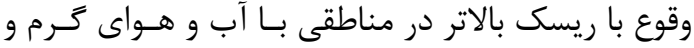
مرطوب به همراه بـارش شـديد بـاران و مقـادير يـائين

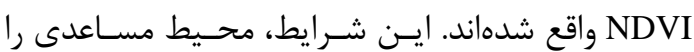

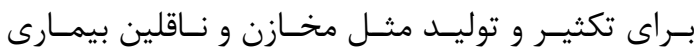
ليتوسييروز فراهم مى كند. نتايج بررسى ارتبـاط ميـان

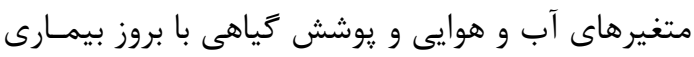
ليتوسييروز در شكل (9) و جدول (Y) ارائه شده است.

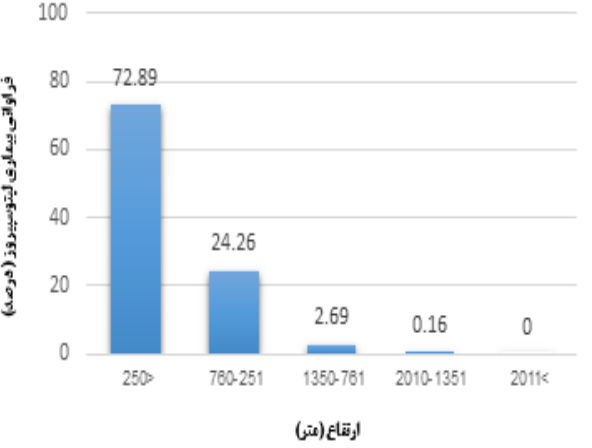

شكل V: فراوانى نسبى (درصد) بيمارى ليتوسبيروز در

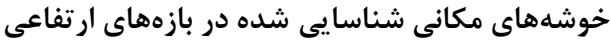

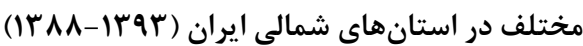

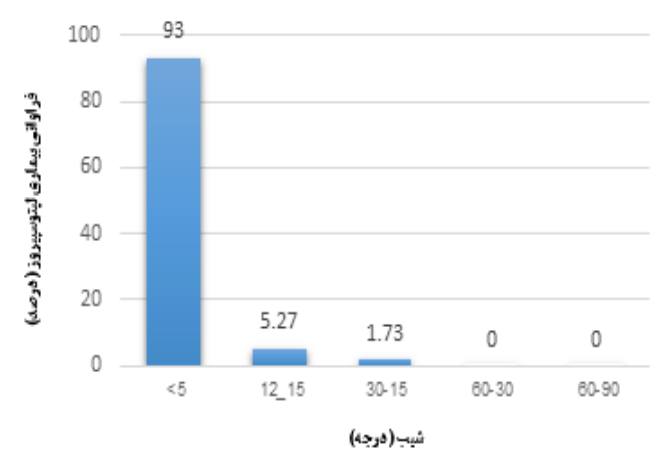

شكل ^: فراوانى نسبى (درصد) بيمارى ليتوسيبروز در

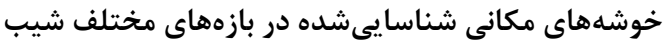

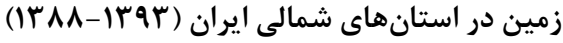

همجنين نتايج آناليز همبستخى پيرسـون، حساكى از آن

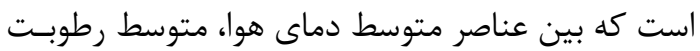

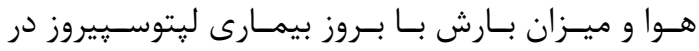

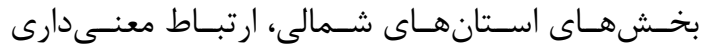

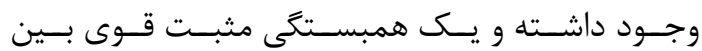
اين متغيرهـا و بـروز بيمـارى لِتوسـيـيروز وجـود دارد.

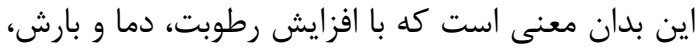

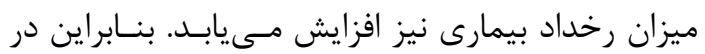

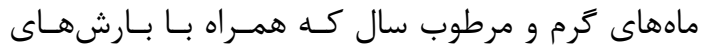
شديد ناشى از بخار آبهاى سـطحى مسى باشــند، مـوارد

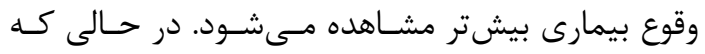

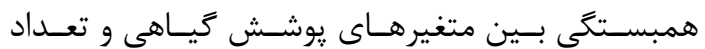

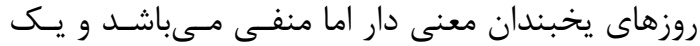



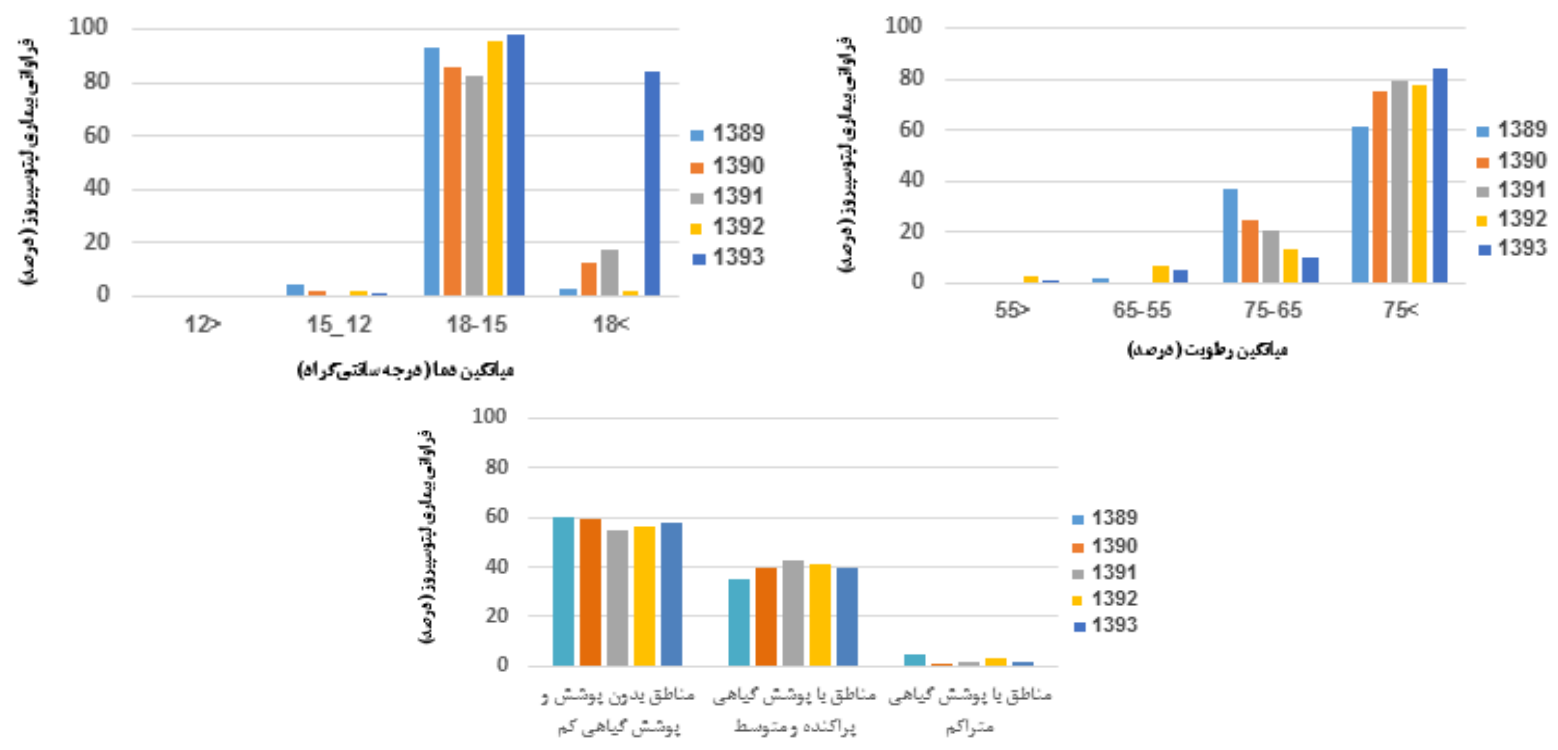

يوشش كميامى
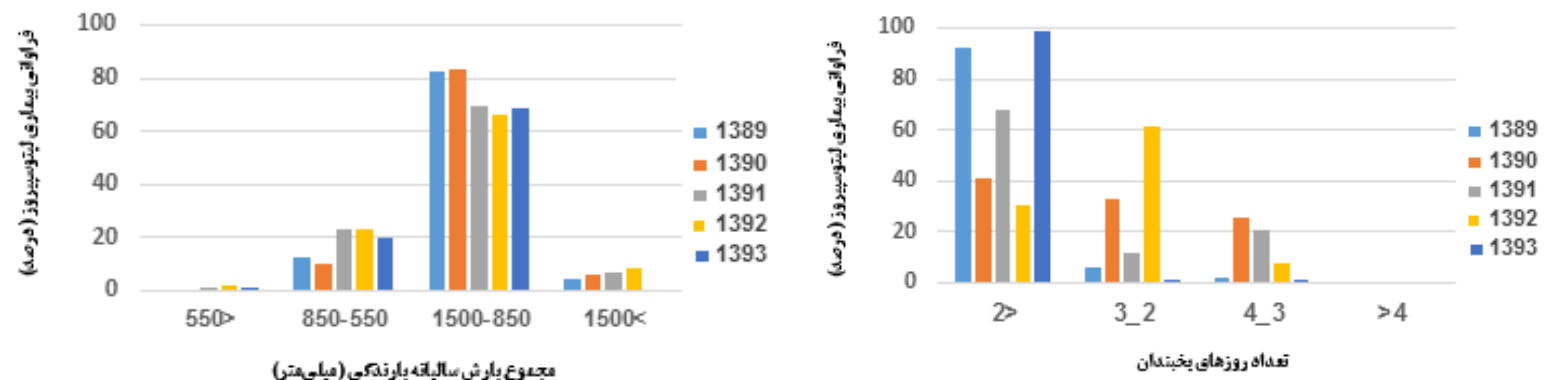

شكل 9: فراوانى نسبى (درصد) بيمارى لِيتوسييروز در طبقات مختلف يرامترهاى محيطى در استان هاى شمالى ايران

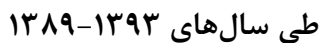

جدول r: نتايج آناليز همبستكى پِيرسون بين متغيرهاى محيطى و تويوگرافى با بروز بيمارى ليتوسييروز در سطح بخشهاى

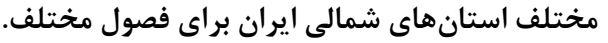

\begin{tabular}{|c|c|c|c|c|c|c|c|c|c|}
\hline نرخ شيوع & تعداد روزهاى & بارش فحموع فصلى & رتوسط & متوسط & يوشَش تَهى & شيب & ارتفاع & & فصل | \\
\hline$\cdot 1 \cdot \vee 9$ & r. & . & -,$\nabla \Delta \Delta$ & 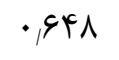 & - • & $-\cdot T \& F$ & $-\cdot, \mu q \vee$ & $\underline{\mathrm{R}}$ & \multirow{2}{*}{ بهار } \\
\hline$\cdot \cdot \Delta$ & r & $\cdot 1 \cdot 1$ & $.1 \cdot 9$ & $\cdot 1 \cdot 1$ & $\cdot 1 \cdot 1$ & $\cdot \cdot \cdot 1$ & $\cdot \cdot \cdot 1$ & $\underline{P}$ & \\
\hline$\cdot / \cdot \Lambda \Lambda$ & $-\cdot . \cdot 9 p$ & $\cdot, \xi \wedge \Lambda$ & . 1991 & $\cdot \gamma \cdot r$ & $-\cdot \mid \wedge r$ & $-\cdot r \cdot r$ &,$- p Y q$ & $\underline{\mathrm{R}}$ & \multirow{2}{*}{ تابستان } \\
\hline$\cdot 1 \cdot 1$ & $\cdot 1 \cdot 1$ & $\cdot \cdot r$ & $\cdot \cdot r$ & $\cdot \cdots 1$ & $\cdot, \cdot 1$ & $\cdot 1 \cdot 1$ & $\cdot \cdot r$ & $\underline{\mathrm{P}}$ & \\
\hline . & $-\cdot 1111$ & • „১৭ & $\cdot, 9 \Delta 1$ & $\cdot, 9 \cdot 1$ & س & $-\cdot T \vee G$ & $\cdot-, \mu V \mathcal{F}$ & $\underline{\mathrm{R}}$ & \multirow{2}{*}{ ياييز } \\
\hline$\cdot$ • & • & $\cdot 1 \cdot 1$ & $\cdot 1 \cdot 1$ & $\cdot 1 \cdot 1$ & $\cdot 1 \cdot 1$ & $\cdot 1 \cdot 1$ & $\cdot . \cdot 1$ & $\underline{\mathrm{P}}$ & \\
\hline
\end{tabular}

توليـــــد شــــــده در شـــــــل (T) (I) و جـــــــدول (r) نقشههاى واقعى و آسـيبـيـذيرى بيمـارى لِيتوسـيروز نشان داده شدهاند. حاصل از مدل SVM براى هر Fأ فصل مربوط بـه سـال

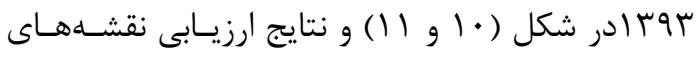



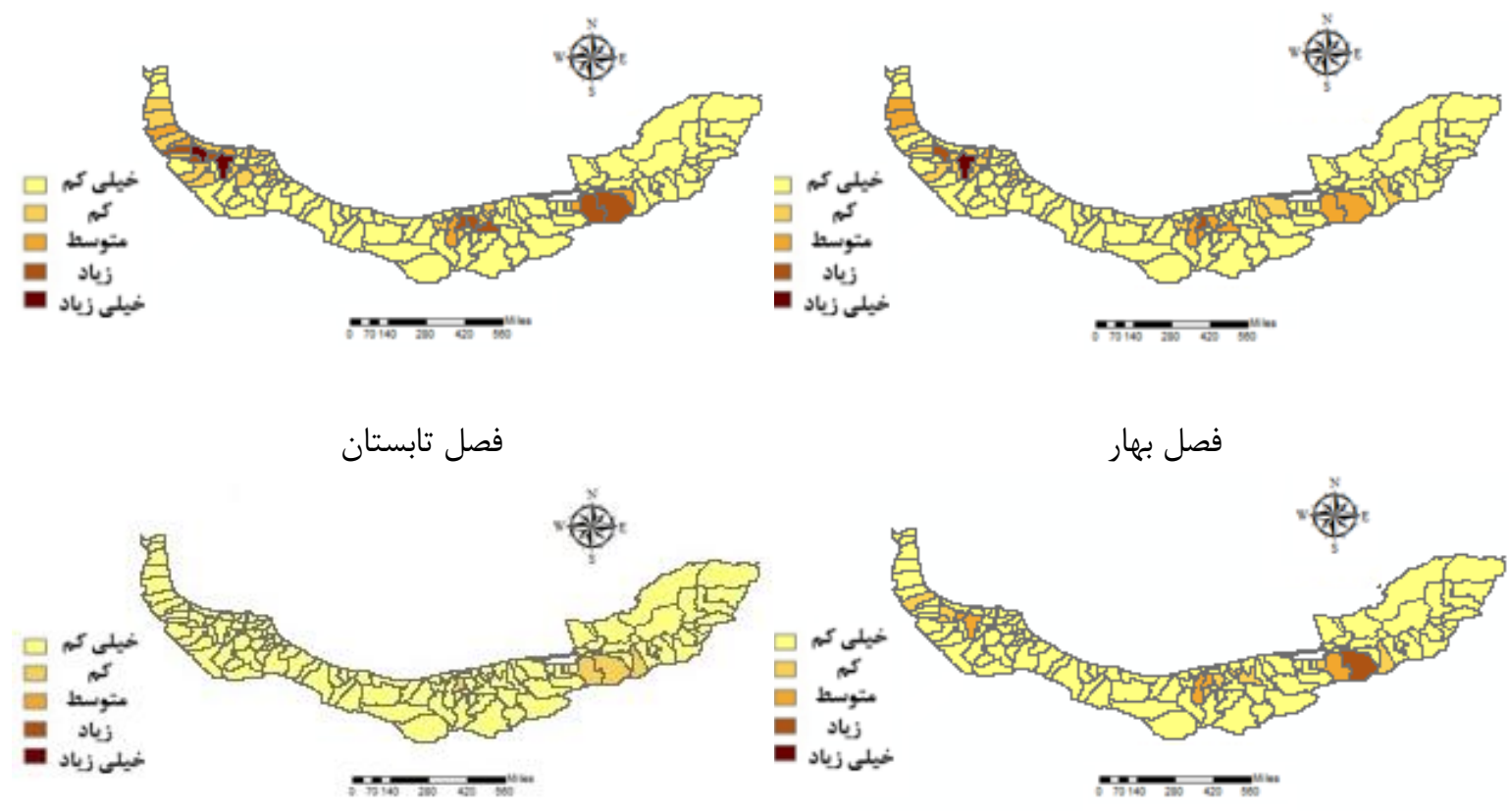

$$
\text { فصل ياييز }
$$

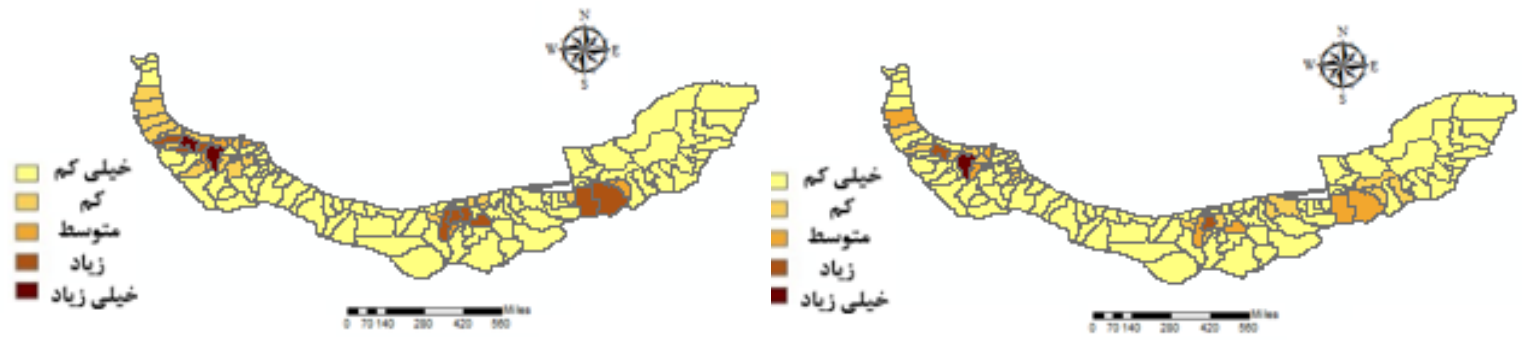

$$
\text { فصل تابستان }
$$

فصل بهار

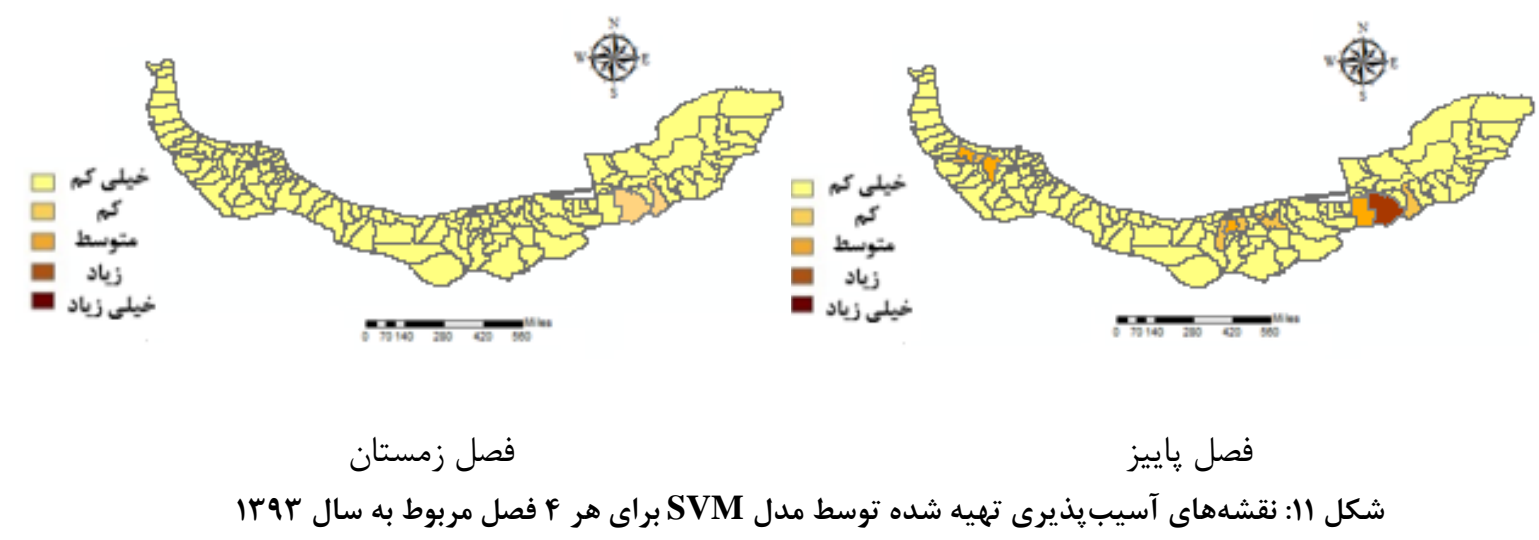




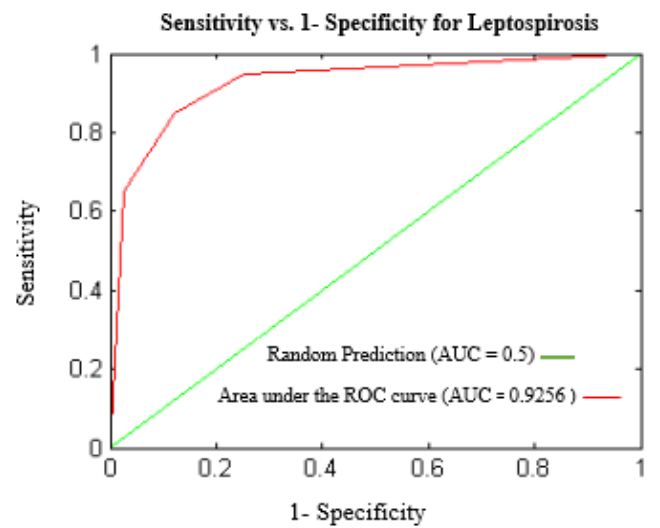

فصل تابستان

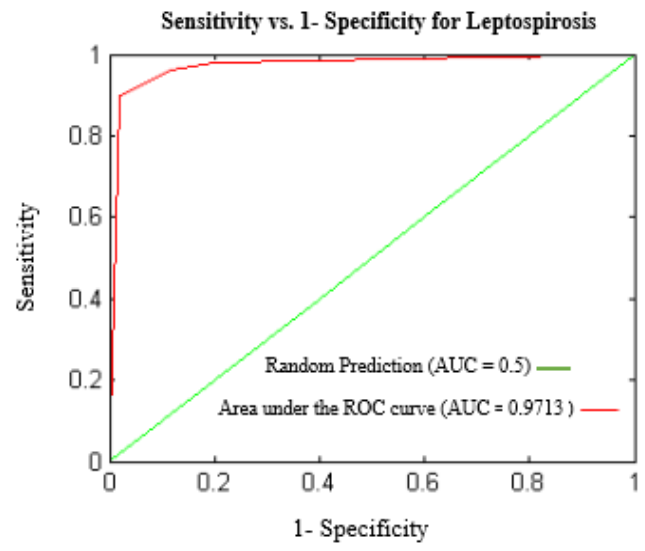

فصل زمستان

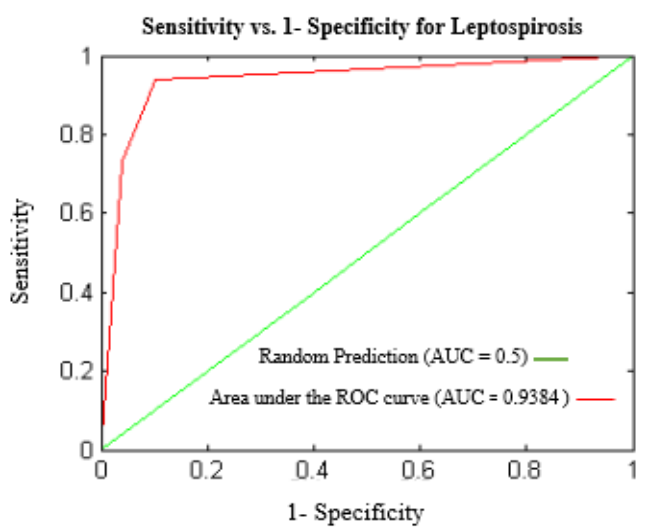

فصل بهار

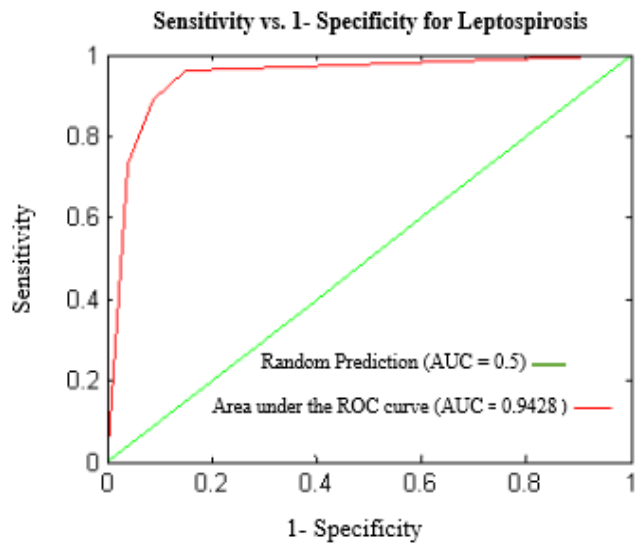

فصل ياييز

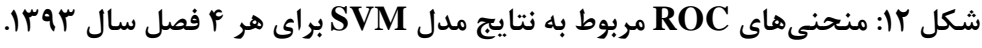

جدول r: جتايج ارزيابى حاصل از مدل SVM

\begin{tabular}{|c|c|c|c|c|}
\hline زمستان & ياييز & تابستان & 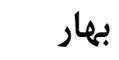 & 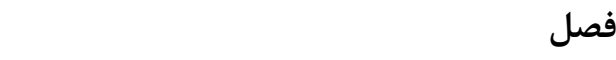 \\
\hline$\cdot 9 \vee 11$ & $\cdot$, qfr人 & • $94 \Delta 9$ & - 9 r人f & مساحت زير منحنى ROC حاصل از مدل SVM \\
\hline
\end{tabular}

آسيب يذيرى تهيه شده در هر فصـل بـهـ همـراه درصـد

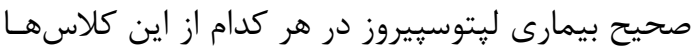

محاسبه شدند (جدول (أ، ه، ؟، لو ^)).
بهمنظور ارزيابى مكانى دقت مدل SVM، بدين صـورت

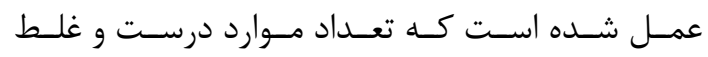

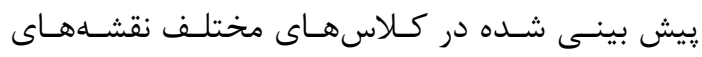

جدول ₹: دقت مكانى مدل SVM در كلاس خيلى كم

\begin{tabular}{|c|c|c|c|c|}
\hline فصل & تعداد موارد در & تعداد موارد در نقشه & تعداد موارد & صرصد \\
\hline بهار & سף & १V & f & 99 \\
\hline تابستان & $\Lambda F$ & $\Lambda \Lambda$ & f & $9 \Delta$ \\
\hline ياييز & $1 \cdot f$ & $1 \cdot 1$ & f & 99 \\
\hline زمستان & 110 & $11 \mathrm{~V}$ & $r$ & 91 \\
\hline
\end{tabular}


جدول ه: دقت مكانى مدل SVM در كلاس كم

\begin{tabular}{|c|c|c|c|c|}
\hline فصل & تعداد موارد در & آسيب يذيرى موارد در نقشيه شده & غعداد موارد & صرصد \\
\hline بهار & If & $1 T$ & $r$ & 19 \\
\hline تابستان & 19 & 19 & r & $\Lambda F$ \\
\hline ياييز & 9 & 9 & r & $9 V$ \\
\hline زمستان & f & $r$ & $r$ & $\Delta$. \\
\hline
\end{tabular}

جدول \&: دقت مكانى مدل SVM در كلاس متوسط

\begin{tabular}{|c|c|c|c|c|}
\hline فصل & تعداد موارد در & آسيب يذاد موارد در نقشه تهيه شده & غعداد موارد & صرصد \\
\hline بهار & 9 & V & $r$ & $\vee \wedge$ \\
\hline تابستان & q & f & $r$ & $9 V$ \\
\hline ياييز & $\Delta$ & f & 1 & $\Lambda$. \\
\hline زمستان & • & • & • & $1 \ldots$ \\
\hline
\end{tabular}

جدول V: دقت مكانى مدل SVM در كلاس زياد

\begin{tabular}{|c|c|c|c|c|}
\hline فصل & تعداد موارد در & آسيب يذاد موارد در نقشه تهيه شده & غعداد موارد & صرصح \\
\hline بهار & $r$ & $r$ & - & $1 \cdots$ \\
\hline تابستان & $\Lambda$ & 9 & 1 & 19 \\
\hline ياييز & 1 & 1 & • & $1 \ldots$ \\
\hline زمستان & • & • & • & $1 \ldots$ \\
\hline
\end{tabular}

جدول ^: دقت مكانى مدل SVM در كلاس خيلى زياد

\begin{tabular}{|c|c|c|c|c|}
\hline فصل & تقداد موارد در & آسيب يذاد موارد در نقشه تهيه شده & غعداد موارد & صرصيح \\
\hline بهار & 1 & 1 & - & $1 \cdots$ \\
\hline تابستان & $r$ & $r$ & • & $1 \cdots$ \\
\hline ياييز & • & • & • & $1 \cdots$ \\
\hline زمستان & . & • & . & $1 \cdots$ \\
\hline
\end{tabular}

بارش شديد باران و در نتيجه افزايش تجمـع آبهــاى سـطحى و راكـد مـى باشـد. همجنــين مطالعـه حاضـر

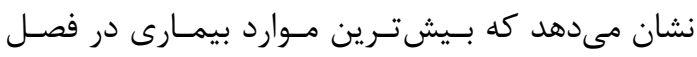
تابستان و اواخر فصل بهار به ثبـت رسـيده و كـمتــرين

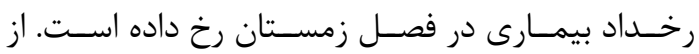

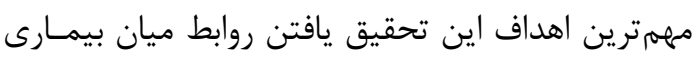

ه- نتيجه كَيرى و ييشنهادات نتايج بهدست آمده از بررسىهاى آمارى، حاكى از وجود

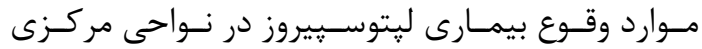
استان گيلان، مناطق شرقى استان مازنـدران و منـاطق

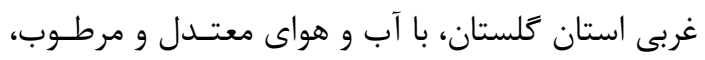




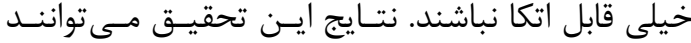

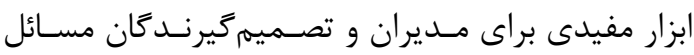

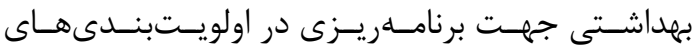

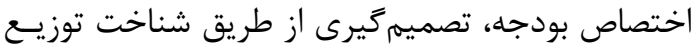

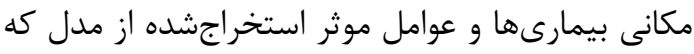

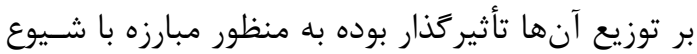

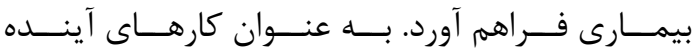

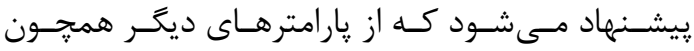

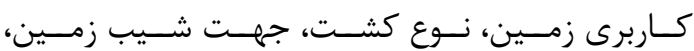

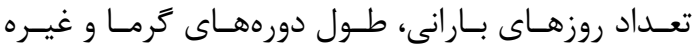

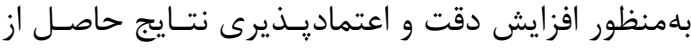

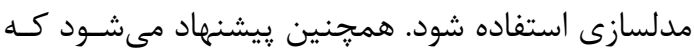

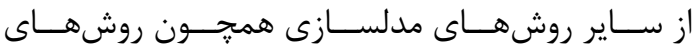
ركرسيونى و شبكههاى عصـبى اسـتفاده شـود و نتـايج

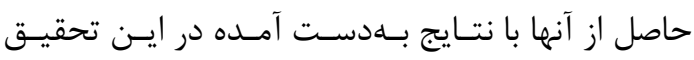

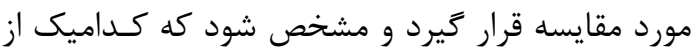

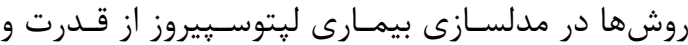
كارايى بيشترى برخوردار مىباشند

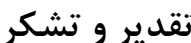

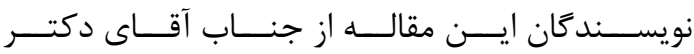

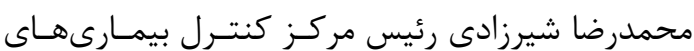

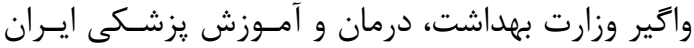

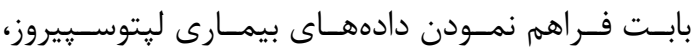
نهايت تشكر و سياس كذارى را دارند.

[1] F. Babamahmoodi, A. G. Âjemi, M. kalhor, A. R. Khalilian, and G. R. shfiei, "A sero epidemiological study of helicobacter pylori infection in Sari in 2001-2002," Journal of Mazandaran University of Medical Sciences, vol. 14, pp. 39-50, 2004.

[2] M. C. Vega-Corredor and J. Opadeyi, "Hydrology and public health: linking human leptospirosis and local hydrological dynamics in Trinidad, West Indies," Earth
و عواملى كه شرايط مسـاعدى را بـراى شـيوع بيمـارى

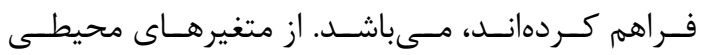
استفاده شده در مدلسازى جنين استنباط مى شـود كـهـ

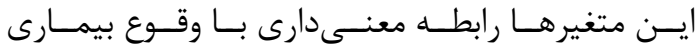

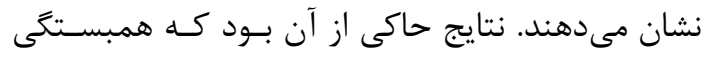

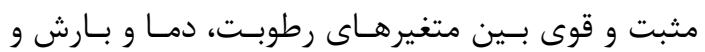
همبستخى منفى و ضعيف بين عناصر يوشش كياهى و

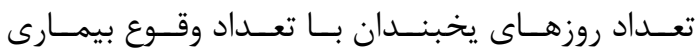

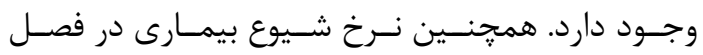
كذشته ضعيفترين همبستكى مثبت را با وقوع بيمارى

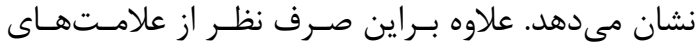

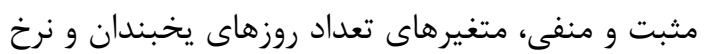

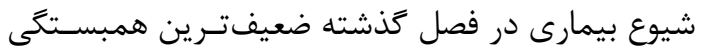

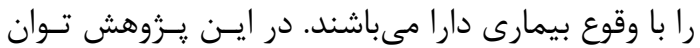

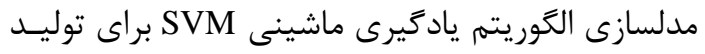

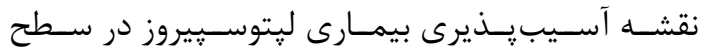
بخشهاى استانهاى شمالى ايران با استفاده از منحنى بئى

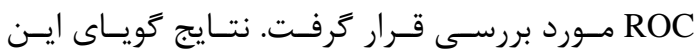

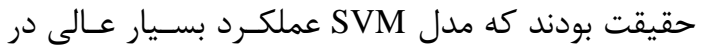

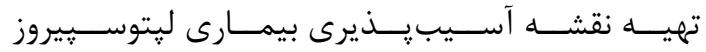
داشته است. مهمترين محدوديت اين تحقيق مربوط بـهـ

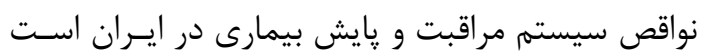
كه جندان دقيق نيست و سالانه شمار قابـل تـوجهى از موارد بيمارى گزارش نمىشوند. محدوديت ديخر مربوط به دوره كوتاه (9 سال) بهدليل فقدان دادههاى بيمـارى

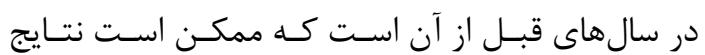

\section{مراجع}

Perspectives, vol. 1, p. 1, 2014.

[3] F. Babamahmodi, N. Motamed, M. Mahdavi, F. Nickhah, and K. Qavi Bonyeh, "Seroepidemiological study of leptospirosis in Ghaemshahr Mazandaran province-Iran, Sept-Oct 2004," Journal of Mazandaran University of Medical Sciences, vol. 16, pp. 51-56, 2006.

[4] H. Honarmand, S. Eshraghi, M. 
Khorramizadeh, R. Hartskeerl, F. Ghanaei, G. Abdolahpour, et al., "Distribution of Human Leptospirosis in Guilan Province, Northern Iran," Iranian Journal of Public Health, vol. 36, pp. 68-72, 2007.

[5] A. Rafiei, A. H. Zadeh-Omran, F. Babamahmoodi, R. A. Navaei, R. Valadan, and I. Sari, "Review of Leptospirosis in Iran," Journal of Mazandaran University of Medical Sciences (JMUMS), vol. 22, 2012.

[6] A. Sh, F. Baba Mahmoudi, N. Najafi, R. Ghasemian, S. Teimouri, and L. Shahbaz Nezhad, "Clinical and paraclinical findings of Leptospirosis in Mazandaran, JuneSemptember 2004," J Mazand Univ Med Sci, vol. 53, pp. 85-78, 2006.

[7] M. AhangarCani, M. Farnaghi, and M. R. Shirzadi, "Predictive Map of SpatioTemporal Distribution of Leptospirosis Using Geographical Weighted Regression and Multilayer Perceptron Neural Network Methods," Journal of Geomatics Science and Technology, vol. 6, pp. 79-98, 2016.

[8] P. A. Burrough, "Principles of geographical information systems for land resources assessment," 1986.

[9] Z. Massoomy and M. S. Mesgari, "PREDICTION OF SKIN CANCER EPIDEMIOLOGY FOR DECISION MAKING USING GEOSTATISTICAL ANALYSES," presented at the ASPRS 2006 Annual Conference, Reno, Nevada, 2006.

[10] [10] S. Keola, M. Tokunaga, N. K. Tripathi, and W. Wisa, "Spatial surveillance of epidemiological disease: a case study in Ayutthaya province, Thailand," GIS@ development, 2002.

[11]S. L. McLafferty, "GIS and health care," Annual review of public health, vol. 24, pp. 25-42, 2003.

[12]D. A. Henderson, "Principles and lessons from the smallpox eradication programme," Bulletin of the World Health Organization, vol. 65, p. 535, 1987.

[13]M. Zare, P. Shamszadeh, and A. Najjari,
"Providing the opportunity to use GIS in decision-making in the health sector management," Hakim, vol. 9, pp. 58-63, 2006.

[14]C. Barcellos and P. C. Sabroza, "The place behind the case: leptospirosis risks and associated environmental conditions in a flood-related outbreak in Rio de Janeiro," Cadernos de Saúde Pública, vol. 17, pp. S59-S67, 2001.

[15] M. Bavia, D. Carneiro, H. da Costa Gurgel, C. M. Filho, and M. R. Barbosa, "Remote sensing and geographic information systems and risk of American visceral leishmaniasis in Bahia, Brazil," Parassitologia, vol. 47, p. $165,2005$.

[16]Z. Pezeshki, M. Tafazzoli-Shadpour, A. Mansourian, B. Eshrati, E. Omidi, and I. Nejadqoli, "Model of cholera dissemination using geographic information systems and fuzzy clustering means: Case study, Chabahar, Iran," Public health, vol. 126, pp. 881-887, 2012.

[17] C. L. Lau, A. C. Clements, C. Skelly, A. J. Dobson, L. D. Smythe, and P. Weinstein, "Leptospirosis in American Samoaestimating and mapping risk using environmental data," PLoS Negl Trop Dis, vol. 6, p. e1669, 2012.

[18] K. Vahdat, I. Nabipour, M. Motamedi, S. M. Jafary, A. Ghajary, M. H. Zafarmand, et al., "A sero-epidemiological survey on leptospirosis in the livestock breeders during the outbreak of haemorrhagic fever in domestic animals of the Helleh River area in 2004," ISMJ, vol. 8, pp. 53-59, 2005.

[19]S. M. Alavi and M. M. Khoshkho, "Seroprevalence study of leptospirosis among rice farmers in khuzestan province, South west iran, 2012," Jundishapur journal of microbiology, vol. 7, 2014.

[20]R. Golsha, B. Khodabakhshi, and A. RAHNAMA, "Leptospirosis in Golestan province in Iran (Reports of twelve cases)," 2007.

[21]H. Faraji, "Prevalence of leptospirosis in 
بررسى تاثير و نقـش عوامـل تويـوكرافى و آب و هــوايى... مهرداد آهنكركانى، مهدى فرنقى، محمدرضا شيرز ادى تئى

Mazandaran province, using microagglutination and indirect fluorescence immunoassay," Iranian Journal of Biology, vol. 22, pp. 608-618, 2009.

[22] R. Esmaili, F. Alhani, A. Hesamzadeh, R. Alizadeh Navaei, and M. Parsaei, "A report of 102 patients with leptospirosis in Mazandaran province between 2003 and 2008," J Mazand Univ Med Sci, vol. 19, pp. 72-75, 2009.

[23] H. Honarmand, G. F. MANSOUR, A. HEYDARZADEH, and M. ASMAR, "Isolation and Serotyping of endemic leptospires of eastern part of flat area of Guilan province, Iran," JOURNAL OF GORGAN UNIVERSITY OF MEDICAL SCIENCES, vol. 11, pp. 53-59, 2009.

[24] A. Mohammadinia, A. Alimohammadi, and R. Habibi, "Assessment of environmental factors associated with rural endemics of Leptospirosis in Guilan Province, Iran," 2015.

[25] A. M. Nia, A. Alimohammadi, R. Habibi, and M. Shirzadi, "Spatial and Statistical Analysis of Leptospirosis in Guilan Province, Iran," The International Archives of Photogrammetry, Remote Sensing and Spatial Information Sciences, vol. 40, p. 497, 2015.

[26] M. Rajabi, A. Mansourian, P. Pilesjö, and A. Bazmani, "Environmental modelling of visceral leishmaniasis by susceptibilitymapping using neural networks: a case study in north-western Iran," Geospatial health, vol. 9, pp. 179-191, 2014.

[27]M. R. Shirzadi, A. Mollalo, and M. R. Yaghoobi-Ershadi, "Dynamic relations between incidence of zoonotic cutaneous leishmaniasis and climatic factors in Golestan Province, Iran," Journal of arthropod-borne diseases, vol. 9, p. 148, 2015.

[28]A. Field, Discovering statistics using IBM SPSS statistics: Sage, 2013.

[29]E. Akbari, E. Mayvaneh, A. Entezari, and M. Nazari, "Survey of the Role of
Bioclimatic Factors in the Outbreak of Cutaneous Leishmaniasis," Iranian Journal of Epidemiology, vol. 10, pp. 65-74, 2014.

[30] J. Benesty, J. Chen, Y. Huang, and I. Cohen, "Pearson correlation coefficient," in Noise reduction in speech processing, ed: Springer, 2009, pp. 1-4.

[31]M. KHAZAEI and H. IZADBAKHSH, "COMBINATION OF DEA AND PCA FOR FULL RANKING OF DECISION MAKING UNITS," journal of Industrial Management, vol. 1, pp. 55-70, 2009.

[32] W. Lu, W. Wang, X. Wang, Z. Xu, and A. Leung, "Using improved neural network model to analyze RSP, NOx and NO2 levels in urban air in Mong Kok, Hong Kong," Environmental Monitoring and Assessment, vol. 87, pp. 235-254, 2003.

[33]C. J. Burges, "A tutorial on support vector machines for pattern recognition," Data mining and knowledge discovery, vol. 2, pp. 121-167, 1998.

[34] Y. Wang, Z. Xue, G. Shen, and J. Xu, "PRINTR: prediction of RNA binding sites in proteins using SVM and profiles," Amino acids, vol. 35, pp. 295-302, 2008.

[35]H. Yu and S. Kim, "Svm tutorialclassification, regression and ranking," in Handbook of Natural computing, ed: Springer, 2012, pp. 479-506.

[36]B. Schölkopf, A. Smola, K.-R. Müller, C. Burges, and V. Vapnik, "Support vector methods in learning and feature extraction," 1998.

[37] K.-B. Duan and S. S. Keerthi, "Which is the best multiclass SVM method? An empirical study," in International Workshop on Multiple Classifier Systems, 2005, pp. 278285.

[38] Y. Liu and Y. F. Zheng, "One-against-all multi-class SVM classification using reliability measures," in Proceedings. 2005 IEEE International Joint Conference on Neural Networks, 2005., 2005, pp. 849-854.

[39] G. Anthony, H. Gregg, and M. Tshilidzi, 
"Image classification using SVMs: oneagainst-one vs one-against-all," arXiv preprint arXiv:0711.2914, 2007.

[40] J. Milgram, M. Cheriet, and R. Sabourin, "“One Against One" or "One Against All": Which One is Better for Handwriting Recognition with SVMs?," in Tenth International Workshop on Frontiers in Handwriting Recognition, 2006.

[41]N. A. Obuchowski, "Receiver Operating Characteristic Curves and Their Use in Radiology 1," Radiology, vol. 229, pp. 3-8, 2003.

[42] S. J. Phillips, R. P. Anderson, and R. E. Schapire, "Maximum entropy modeling of species geographic distributions," Ecological modelling, vol. 190, pp. 231-259, 2006.

[43]D. M. Powers, "Evaluation: from precision, recall and F-measure to ROC, informedness, markedness and correlation," 2011. 


\title{
Exploring the Impact of Topographical and Climate Factors on Generation of the Vulnerability-map of Leptospirosis
}

\author{
Mehrdad Ahangarcani ${ }^{1}$, Mahdi Farnaghi ${ }^{* 2}$, Mohammad Reza Shirzadi ${ }^{3}$ \\ 1- M.Sc student of geographic information system, Faculty of Geodesy and Geomatics, K. N. Toosi University of Technology \\ 2- Assitant Professor, Faculty of Geodesy and Geomatics, K. N. Toosi University of Technology \\ 3- Center for Disease Control (CDC), Ministry of Health and Medical Education
}

\begin{abstract}
Leptospirosis is one of the most widespread zoonotic disease caused by Leptospira bacteria. It is found wherever human is in direct or indirect contact with Leptospira bacteria thorough infected animals as well as contaminated soil or water. The disease is mostly found in tropical, subtropical, hot, and humid areas. The main objectives of this study are to investigate the seasonality relations between the topographical and climate factors, including altitude, slope, vegetation, average temperature, average humidity, precipitation and number of freezing days and incidence of Leptospirosis as well as modelling of Leptospirosis using support vector machine at the district level in Northern provinces of Iran. Pearson's correlation analysis was conducted to examine the type and strength of relationships between the topographical and climate variables and Leptospirosis incidence. Results of Pearson's correlation analysis indicate that average humidity, average temperature and rainfall were the most influential environmental factors which as effect on prevalence of Leptospirosis in the study area. Statistical analysis showed that most cases of the Leptospirosis prevalence have been recorded in the late spring and summer. On the other hand, the lowest incidences have occurred in winter. Also, high distribution of leptospirosis mainly located in the central areas of Guilan province, the eastern parts of Mazandaran province and western regions of Golestan province with a mild and humid climate and abundant rainfall. Eventually, performance of support vector machine (SVM) model evaluated by area under the ROC curve. The output maps showed that SVM model has excellent performance in the vulnerability mapping of Leptospirosis.
\end{abstract}

Key words: Pearson's analysis, geographic information system, support vector machine, ROC curve, Leptospirosis

Correspondence Address Geospatial Information System Group, Faculty of Geodesy and Geomatics Engineering, K.N.Toosi University of Technology, Tehran, Iran

Tel : +989122432847

Email: farnaghi@kntu.ac.ir 